\title{
Environmental Regulation and International Competitiveness
}

\author{
Richard B. Stewart ${ }^{\dagger}$
}

\section{CONTENTS}

I. INTRODUCTION: THE CONTEMPORARY DEBATE OVER TRADE, ENVIRONMENTAL MEASURES, AND COMPETTTIVENESS . . . . . . . . 2041
A. Product Regulation . . . . . . . . . . . . . . . . . 2043
B. Process Regulation . . . . . . . . . . . . . . . . . . . 2044
C. The Policy Debate in the United States . . . . . . . . . . 2045

II. ENVIRonmental Process Regulation, Liability Rules, AND

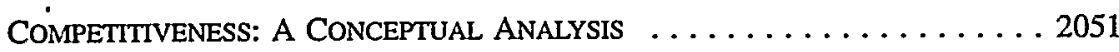

A. Explaining Differences in Environmental Standards Among Nations . . 2052

1. Differing Assimilative Capacities . . . . . . . . . . . 2052

2. Political Failure ...................... 2054

3. Externalities ...................... 2054

B. Effects of Differing National Environmental Requirements on Competitiveness . . . . . . . . . . . . . . . . 2056

C. Desirability of International Competition in Assimilative Capacity . . . 2057

III. PROCESS REgulation AND INTERNATIONAL COMPETTTIVENESS:

EMPIRICAL STUDIES . . . . . . . . . . . . . . . 2061

A. Inherent Difficulties in Measuring the Costs of Environmental

Regulations and Liability Rules . . . . . . . . . . . 2062

1. The Invisible Costs of Investments and Innovations Forgone . . . . 2063

2. The Benefits of Environmental Regulation . . . . . . . . . 2065

3. The Indirect Effects of Industry Regulation on the Economy as a Whole ........................... 2066

B. Special Problems in Comparative Studies . . . . . . . . . . . 2067

1. Obsolescence of Data . . . . . . . . . . . . . . . 2068

2. Different Regulatory and Enforcement Systems .......... 2068

$\dagger$ Professor of Law, New York University Law School; Counsel, Sidley \& Austin. The research assistance of Eric Cohen, Michael Naughton, and James Reilly is gratefully acknowledged. Thanks are also due to Lewis Kornhauser and Ricky Revesz for perceptive comments. 
3. Industries Exceeding Minimum Standards . . . . . . . . . . . . 2070

C. Review of the Empirical Studies . . . . . . . . . . . . . . . 2071

1. Productivity Studies . . . . . . . . . . . . . . . 2072

2. Trade Studies . . . . . . . . . . . . . . . . . . . . . . 2074

3. Locational Studies . . . . . . . . . . . . . . . . . . . . . . . . 2077

4. "The Race to the Top" ... . . . . . . . . . . . . . . . . . . 2079

5. Long-run Impact on Innovation and Investment . . . . . . . . 2082

IV. Evaluation . . . . . . . . . . . . . . . . . . . . . . . . . . 2084

A. The Competitiveness Impacts of National Differences in Environmental Regulation and Liability Rules . . . . . . . . . 2084

B. Reexamining U.S. Environmental Priorities and the Means for Achieving Them . . . . . . . . . . . . . . . . . . . 2086

1. Environmental Contracting . . . . . . . . . . . . 2090

2. Market-Based Incentives for Environmental Protection . . . . . . . 2093

C. International Harmonization of Environmental Standards . . . . . . . 2097

1. Justifications for Harmonization . . . . . . . . . . . . . 2097

2. Precedents for International Harmonization $\ldots \ldots \ldots \ldots \ldots \ldots 2100$

3. Competitiveness Concerns as Impediments to International Agreement . . . . . . . . . . . . . . . 2102

4. The Use of Economic Incentives in International Harmonization . . 2104

V. Conclusion: Competitiveness as a Political Heuristic $\ldots \ldots \ldots \ldots 2105$

The world is simultaneously facing increasing economic interdependency and intensified demands for protecting the environment. The June 1992 United Nations Conference on Environment and Development (UNCED) in Rio ${ }^{1}$ has stimulated awareness of the global character of many environmental problems and the impact of environmental regulation on economic growth. ${ }^{2}$ At the same time, businesses and nations increasingly are concerned about their ability to compete in the international marketplace. Nations such as the U.S. that adopt stringent environmental protection measures fear that they will be disadvantaged in that competition. This Article examines the potential conflicts between environmental protection and international trade and competition and considers how they might be accommodated.

The methodological premise of the Article is that nations are the primary actors in environmental policy. It is still premature to speak of a global

1. For a review of conference proceedings, see Rio Conference on Environment and Development, 22 ENVTL. POL'Y \& L. 204 (1992).

2. See id. at 204. 
political or social community. Nations are driven by economic self-interest and the search for strategic advantage in an international economy in which trade and capital mobility play an increasingly important role. It would, however, be wrong to focus solely on international competitiveness. National policies are also driven, in varying degrees, by environmental concerns. These concerns may include protection of the global ecosyste $\mathrm{m}^{3}$ and the well-being of future generations $s^{4}$ as well as promotion of the local health and environmental concerns of present generations. Protecting the environment while meeting the worldwide demand for economic growth will in many instances require joint efforts among nations. The process of building these joint efforts will itself affect and perhaps strengthen national concerns with the global, long-run elements of environmental protection. Nevertheless, efforts to build cooperation must also deal with, and therefore require an understanding of, global economic rivalry and its impact on domestic and international politics.

This Article argues that a nation's imposition of stringent environmental regulation and liability rules may harm its international competitiveness, even though most empirical studies have not established a strong causal association between the two. This threat is especially significant in the U.S., due to the exceptionally complex, burdensome and costly character of its regulatory and legal system. Focusing solely on competitiveness, however, is myopic. The contributions that a cleaner environment and resource conservation make to well-being must also be taken into account. What ultimately matters is the broad overall performance of the economy, including the environmental and health benefits generated by governmental programs for environmental protection. Issues of competitiveness and trade nonetheless have high political visibility, particularly when they are manifest in plant closings and relocations. The appropriate response to competitive concerns is not autarchy. The U.S. should not attempt to insulate itself by barring or imposing discriminatory duties on products from nations with less stringent standards. Rather, the solution is a combination of domestic policy changes to eliminate unnecessary regulatory and liability burdens, and international efforts to move toward partial harmonization of national environmental measures. These changes would also advance environmental objectives.

\section{INTRODUCTION: THE CONTEMPORARY DEBATE OVER TRADE, ENVIRONMENTAL MEASURES, AND COMPETITIVENESS}

The accomplishments of the General Agreement on Tariffs and Trade (GATT) in lowering tariffs and other barriers to trade have helped create a

3. See Alfred C. Aman, Jr., The Earth As Eggshell Victim: A Global Perspective on Domestic Regulation, 102 YALE L.J. 2107, 2107-09 (1993).

4. See Edith Brown Weiss, Environmentally Sustainable Competitiveness: A Commentary, 102 YALE L.J. 2123, 2123 (1993). 
global marketplace in goods and services. The GATT was adopted in 1947 in order to promote trade liberalization. ${ }^{5}$ Trade advances global welfare by promoting specialization in accordance with comparative advantage, expanding opportunities to realize scale economies, tightening the discipline of competition, and stimulating wide dissemination of knowledge and technological innovation. ${ }^{6}$ Empirical studies confirm that trade liberalization promotes economic growth; the liberalization spurred by GATT has been an important factor in global post-World War II prosperity. ${ }^{7}$ As a result of these and other developments, investment capital has become internationally mobile. Multinational manufacturing companies seeking to cut costs in the "struggle for the world product" have divided their operations into separate units: raw materials processing, manufacture of components, assembly, and distribution. On the basis of worldwide searches, they have sought to situate units in locations that will yield the lowest total production costs. Nations are struggling to attract investment and operations that will add value to their economies and strengthen their position in international trade.9

In order to understand the relationship between these developments and governmental measures for environmental protection, one must distinguish between measures aimed at products and those aimed at processes. Examples of product measures include the regulation of pesticide residues in food, taxes on the lead content of fuels, and product liability rules. Examples of process measures include water pollution discharge regulation, mining reclamation laws, tradeable permit programs designed to limit sulfur emissions from utilities, and liability for hazardous waste damage and cleanup. ${ }^{10}$

Distinguishing between the two is important for several reasons. First, the relationships among trade, competitiveness, and variations in national environmental measures are quite different in the two contexts. In the case of product regulation, a nation that adopts relatively stringent standards can prevent some of the adverse impacts on the competitiveness of its industry by restricting import competition. In the case of process standards, a nation with more stringent standards cannot unilaterally neutralize its industry's disadvantage in international competition. Second, it is inherently easier for

5. See generally JOHN H. JACKSON, WORLD TRADE AND THE LAW OF GATT (1969) (describing GATT as a major multilateral agreement whose design was based on the premise that international regulation would foster international trade).

6. See ANne O. KRueger, Perspectives on Trade and Development 57-62 (1990); Marian Radetzki, Economic Growth and Environment, in 159 WORLD BANK DISCUSSION PAPERS: INTERNATIONAL TRADE AND THE ENVIRONMENT 121, 121 (Patrick Low ed., 1992) [hereinafter WORLD BaNK PAPERS].

7. See JAGDiSh BHAGWATI, PROTECTIONISM 7-9 (1988); KRUEGer, supra note 6, at 206-212.

8. See H. JEFrREY LEONARD, POLLUTION AND THE STRUGGLE FOR THE WORLD PRODUCt 55 \& n.2 (1988) (quoting Helmut Schmidt, The Struggle for the World Product, 52 FOREIGN AFF. 437, 437 (1974)).

9. See LeONARD, supra note 8, at 20-53; Michael E. PoRTER, The COMPETITIVE ADVANTAGE OF NATIONS 29-30 (1990); ROBERT B. REICH, THE WORK OF NATIONS 110-53 (1991).

10. Product and process measures are discussed in detail in Richard B. Stewart, International Trade and the Environment: Lessons From the Federal Experience, 49 WASH. \& LEE L. REV. 1329, 1333-37, 1340-45 (1992). 
nations to harmonize their product regulations than their process regulations, in part because nations have stronger economic incentives to do so, as will be argued in the following Section.

\section{A. Product Regulation}

Products trade in world markets. A nation that adopts comparatively stringent and costly product regulations can, however, prevent international competition from harming its industry by excluding or prohibiting the sale of noncomplying imports. Even if the same standards are applied to domestic and imported products, producers in nations with more stringent standards are likely to enjoy scale economies in complying with their nation's more stringent regulatory requirements and thus obtain a competitive advantage over importers. " For example, German producers have complained that Danish container recycling requirements undercut their ability to compete with Danish brewers in the Danish market. ${ }^{12}$ To the extent that a global market for "green" products and technologies emerges, a nation that adopts stringent standards may also confer an eventual competitive advantage on its industry by giving it incentives to develop such technologies. ${ }^{13}$ On the other hand, to the extent that other nations do not adopt stringent standards, that nation's industry may suffer a cost disadvantage in foreign markets. ${ }^{14}$

In addition, facially nondiscriminatory product regulations are often designed in such a way as to give a competitive advantage to local firms. For example, the U.S. banned imports of Canadian lobsters that did not meet the minimum size requirements imposed on lobsters harvested in the U.S., despite evidence that Canadian lobsters are naturally smaller because Canadian waters are colder. ${ }^{15}$ The disputes between the U.S. and the European Community (EC) over the U.S. ban on EC wine containing trace residues of pesticides and the EC ban on U.S. beef from cattle that had received bovine growth hormones are also illustrations of environmental and health measures that have been attacked as disguised trade restrictions. ${ }^{16}$

11. Domestic producers are also likely to be more familiar with the domestic regulatory and legal system and therefore better able to deal with it.

12. The European Court of Justice upheld most aspects of the Danish law against a claim by the European Commission that the law unlawfully interfered with the common market. See Case 302/86, Commission v. Denmark (Re Disposable Beer Cans), 1988 E.C.R. 4607, 1 C.M.L.R. 619 (1989) (upholding deposit-and-return system on containers, but striking down requirement that only certain approved containers could be used as violation of Article $30 \mathrm{EEC}$ ).

13. See infra notes $206-207$.

14. This disadvantage is likely to occur if the "green" product is more costly. If manufacturers in the nation with stringent standards sold the green product abroad, they would incur a cost disadvantage. If they manufactured a separate product for sale abroad, they might sacrifice economies of scale and thereby also incur a cost disadvantage.

15. See Lobsters from Canada, 1990 WL 299945 (U.S. Can. F.T.A. Binat. Panel, May 25, 1990) (upholding U.S. ban).

16. See Ban on Some European Wines May End, N.Y. TIMES, Feb. 2, 1991, at 10; Don't Let 
All nations and producers have a basic common interest in harmonizing their product regulations in order to reduce transaction costs, efforts at disguised protectionism, and other trade barriers resulting from differences in national standards. Harmonization promotes the advantages of a more extensive product market: specialization, scale economies, and increased competition. The importance of these factors is reflected in the proposed North American Free Trade Agreement (NAFTA), which has extensive provisions designed to promote harmonization of product standards. ${ }^{17}$ To be sure, it is not always easy to agree on common standards. Differences in environmental, social, and economic conditions among nations may make different product standards appropriate. ${ }^{18}$ Environmental groups fear that harmonization will weaken standards in the U.S. and other nations with the most stringent standards, while producers in developing nations complain that they cannot afford to comply with more stringent requirements. ${ }^{19}$

\section{B. Process Regulation}

The potential conflicts between trade, competitiveness, and process regulation and liability rules are different, more serious, and more intractable. Producers in countries with more stringent regulatory requirements and expansive liability rules will incur higher costs in complying with regulatory requirements and avoiding liability. These higher costs will, other things being equal, disadvantage such producers competing in both domestic and international markets. Nations with more stringent process standards might seek to exclude or impose special duties on products imported from nations with less stringent process standards. Such measures, however, are probably

Hormones Start a Trade War, N.Y. TIMES, Dec. 28, 1988, at A26; High-Quality Beef Exports to EC to Resume with Partial Resolution of Hormone Dispute, 6 Int'l Trade Rep. (BNA) 577 (1989), available in LEXIS, BNA Library, INTRAD File; Sue Kirchhoff, U.S. Sets Fungicide Limit, Ending Wine Dispute with France, REUTER BUS. REP., Feb. 1, 1991, available in LEXIS, Nexis Library, BUSRPT File; William Tuohy, U.S. Trade War Looms as Europe's Meat Ban Takes Effect, L.A. TIMES, Jan. 1, 1989, at 8.

Product liability rules may also affect international competition, but in different ways from product regulation. For example, U.S. firms complain that U.S. product liability laws constrain the development and adoption of new products in competition with foreign manufacturers because U.S. manufacturers, with a larger share of the U.S. market, face much greater liability exposure if a new product is later judged defective. On the other hand, manufacturers in other countries complain that U.S. product liability laws operate as a trade barrier. Clarence E. Maggludd \& Herbert A. Igbanugo, Are U.S. Product Liability Laws Acting as a Trade Barrier to the Detriment of U.S. Companies?, 42 FED'N INS. \& CORP. COUNS. Q. 347 , 358 (1992).

17. See North American Free Trade Agreement, chs. 7B (Sanitary and phytosanitary measures), 9 (general standards-related measures), available in WESTLAW, NAFTA Database.

18. See infra notes 58-65 and accompanying text.

19. See Matthew Hunter Hurlock, Note, The GATT, U.S. Law, and the Environment: A Proposal to Amend the GATT in Light of the Tuna/Dolphin Decision, 92 CoLuM. L. REv. 2098, 2131-33 (1992); John Burgess, Competing in a Diverse Market; U.S. Firms Seek Unity on Product Standards in Europe, WASH. PosT, Dec. 2, 1991, at A1. 
illegal under international trade law ${ }^{20}$ and cannot insulate domestic producers from the competitive disadvantage they face in the world market. Nor can nations with more stringent standards prevent multinationals from moving operations to nations with laxer environmental requirements.

Nations with more stringent process standards could seek to remove their competitive disadvantage by securing international agreement on common standards. However, the common interest in harmonizing process standards is typically weaker than the common interest in harmonizing product standards, where harmonization can increase the economic welfare of all nations by removing trade barriers. ${ }^{21}$ Differences in process measures by themselves do not create trade barriers. Nations that have adopted less stringent standards presumably wish to retain whatever economic benefits, including competitive advantages, that such standards confer. There is also no well-established international institution, comparable to the GATT, to serve as a forum for harmonizing process standards. Finally, it is far more difficult to monitor and enforce compliance with common process measures than it is compliance with product standards.

\section{The Policy Debate in the United States}

During the last ten years there has been growing concern in the U.S. about the interplay between trade, environmental regulation, and international competitiveness. ${ }^{22}$ Some of the concern has focused on product regulation. ${ }^{23}$ While environmentalists have worried that harmonization would result in a weakening of relatively stringent U.S. standards, industry has generally supported international harmonization of product regulatory standards. ${ }^{24}$ Most

20. See General Agreement on Tariffs and Trade: Dispute Settlement Panel Report on United States Restrictions on Imports of Tuna, Aug. 16, 1991, 30 I.L.M. 1594 (derestricted Nov. 29, 1991) (invalidating U.S. ban on imports of tuna caught on the high seas by Mexican fishing boats that failed to comply with U.S. restrictions on the incidental take of dolphins) [hereinafter GATT Ruling].

21. For this reason, European Community environmental legislation establishing uniform standards for process regulation is less extensive than legislation regarding product regulation, and is not fully implemented in many member states. See Richard B. Stewart, Environmental Law in the United States and the European Community: Spillovers, Cooperation, Rivalry, Institutions (unpublished manuscript, on file with author).

22. See LEONARD, supra note 8, at 70-82. This concern is reflected in the growing literature on the subject. See, e.g., Dale W. Jorgenson \& Peter J. Wilcoxen, Environmental Regulation and U.S. Economic Growth, 21 RAND J. ECON. 314 (1990); Joseph P. Kalt, The Impact of Domestic Environmental Regulatory Policies on U.S. International Competitiveness, in INTERNATIONAL COMPETITIVENESS 221 (A. Michael Spence \& Heather A. Hazard eds., 1988).

23. See Patti Goldman, The Legal Effect of Trade Agreements on Domestic Health and Environmental Regulations, 7 J. ENVTL. L. \& LmG. 11 (1992); Robert L. Heckart and Tira Harpaz, Critics Ask if NAFTA is "Green" Enough, NAT'L L.J., Dec. 21, 1992, at 17 (citing concern about NAFTA environmental provisions).

24. See Statement of the United States Council for International Business on an Integrated Approach to Environment and Trade Issues 1, 6 (Mar. 27, 1991) (on file with author). For further discussion on the harmonization issue, see Burgess, supra note 19 at A1; CVM, EC To Consider Joint Review of NADAs, 34 FOOD CHEMICAL NEwS 32, Oct. 5, 1992, available in LEXIS, Nexis Library, ZCPG1 File; Virginia Kent 
of the attention, however, has been directed at process regulation. The U.S. has the most expansive liability rules for environmental pollution and among the most stringent environmental regulatory requirements in the world. ${ }^{25}$ As a result, many fear, the competitiveness of U.S. firms has been impaired; the nation's ability to attract and retain industry has been seriously undermined. ${ }^{26}$ Industry has repeatedly invoked the specter of international competitive disadvantage in opposing stricter environmental standards. ${ }^{27}$

These concerns have fueled debate over the proposed North American Free Trade Agreement (NAFTA) with Mexico. ${ }^{28}$ Some environmental and union groups have asserted that if trade with Mexico is liberalized, Mexico's weaker environmental requirements will lead U.S. industry to relocate there. ${ }^{29}$ The "Reagan-Bush version of "free trade" has been attacked as producing a situation where "the lowest common denominator prevails" in environmental regulation. ${ }^{30}$ Politicians, invoking the concept of "fair trade," have denounced "pollution havens," and voiced concern that competition among nations in regulation will result in a "race to the bottom," substantially weakening U.S. regulatory standards. ${ }^{31}$ President Clinton has asserted, in connection with NAFTA, that Mexico should tighten its environmental standards "so we don't have people running down there so they can evade all the Clean Air Act" requirements. ${ }^{32}$

Dorris, Standards for a Global Market, 224 ENG'G NEwS-RECORD 16, Apr. 19, 1990, at 24, available in LEXIS, Nexis Library, ENR File; FAO, CODEX, GATT Preventing Trade Barriers: Lupien, 40 FOOD CHEMICAL NEws 34, Nov. 30, 1992, available in LEXIS, Nexis Library, ZCPGI File; OECD Group Views International Development of Product Safety Measures, Standardization, Int'1 Trade Rep. (BNA), Jan. 8, 1986, available in LEXIS, BNA Library, INTRAD File.

25. See Angus Macbeth, Tort Law, Environmental Law Share Common Ground, LEGAL TiMES, Feb. 15,1982 , at 35 . The U.S. also has the world's most expansive product liability standards, which can also affect competitiveness. See supra note 16.

26. See infra notes 29-33, 37-38 and accompanying text; LEONARD, supra note 8, at 74-79; Not Guilty, ECONOMIST, Feb. 13, 1993, at 63.

27. See Matthew L. Wald, Industry Wary of Clean-Air Bill, N.Y. TIMES, Apr. 5, 1990, at D1 (industry opposes new environmental regulatory requirements as detrimental to U.S. industry).

28. NAFTA would create a free trade area that would include Canada, Mexico, and the U.S. NAFTA has been signed by representatives of all three nations, but must be approved by the U.S. Congress and the other signatory governments. See generally GARY CLYDE HUFBAUER AND JEFFREY J. SCHOTT, NORTH AMERICAN FREE TRADE: ISSUES AND RECOMMENDATIONS (1992) (studying substance and form of possible NAFTA). On the debate over NAFTA, see Frances Lee Ansley, North American Free Trade Agreement: The Public Debate, 22 GA. J. INT'L \& COMP. L. 329 (1992).

29. See Environmentalists, Labor, Others Join in Conference on International Trade, Int'l Env't Daily (BNA), Aug. 27, 1992, available in LEXIS, Nexis Library, BNAIED File; Stephen L. Kass and Michael B. Gerrard, The North American Free Trade Agreement, N.Y. L.J., Nov. 27, 1992, at 3.

30. Peter DeFazio, The Environmental Cost of Free Trade, 7 J. ENVTL. L. \& LiTIG. 9 (1992). The author is a Member of Congress from Oregon.

31. See NAFTA: Hearings Before the Subcomm. on Int'l Trade of the Senate Comm. on Finance, 102d Cong., 2d Sess. (1992); Baucus Says NAFTA Still Needs to Bridge Gap on Mexican Environmental Enforcement, 1992 Daily Rep. for Executives (BNA) No. 130, at D-14 (July 7, 1992), available in LEXIS, Nexis Library, DREXEC File; NAFTA: No Direct Sanctions Allowed if Mexico Lax in Environmental Enforcement, Reilly Says, Int'l Trade Daily (BNA), Sept. 17, 1992, available in LEXIS, Nexis Library, BNAITD File.

32. Clinton Endorses NAFTA But Says Pact Needs to be Strengthened, Int'l Trade Daily (BNA), Feb. 22, 1993, available in LEXIS, Nexis Library, BNAITD File. 
Most U.S. environmental groups and much of U.S. industry, along with many politicians, believe that more stringent U.S. regulatory standards entail significant competitive disadvantage for the nation. ${ }^{33}$ There are, however, dissenting views. ${ }^{34}$ Internationally oriented, export-based industry representatives have downplayed the competitiveness significance of environmental requirements. ${ }^{35}$ Some environmental groups have rejected claims of competitive disadvantage and "industrial flight,"36 perhaps fearing that to accept them would lead to weakening of U.S. requirements.

While the dominant view is that the competitiveness problem is a serious one, different interest groups propose conflicting approaches to solve the problem. Industry has argued that U.S. environmental regulation and liability rules have significantly harmed the international competitiveness of U.S. business, and that the solution is to relax the stringency of our requirements. ${ }^{37}$ This was the basic approach taken by the Reagan Administration. ${ }^{38}$ Environmental groups, on the other hand, have asserted that the problem is not one of overly stringent U.S. regulation, but rather unduly lax regulation in other nations. They argue that the solution is not to weaken U.S. standards but to persuade or require other nations to strengthen theirs in order to eliminate the unfair competitive disadvantage that they now enjoy ${ }^{39}$ International harmonization of standards, the argue, could be achieved through international

33. See Chevron CEO Highlights Consequences of Excessive Regulatory Burden on Business, WORLDWIDE ENERGY, Oct. 1992; David Dodwell, Environment Better Served by Free-Trade Carrot Than Protectionist Stick, FIN. TIMES, May 13, 1992, at 4; David Rudnick, Taken to the Cleaners, THE TIMES (London), June 16, 1992; Matthew L. Wald, Searching for Incentives to Entice Polluters, N.Y. TIMES, Oct. $8,1989, \S 3$, at 8 .

34. See, e.g., David Crane, "Pollution Havens" Found Poor Way to Increase Profits, ToRoNTo STAR, Nov. 14, 1991, at D2; Robert Sangeorge, Industries not Fleeing to "Pollution Havens," UPI, Nov. 9, 1982, available in LEXIS, Nexis Library, UPI File; World Bank Says Environmental Policy not Forcing Industry to Move Out of U.S., 1992 Daily Rep. for Executives (BNA) No. 34, at A-20 (Feb. 20, 1992), available in LEXIS, Nexis Library, DREXEC File.

35. See, e.g., Trade and the Environment, Hearings on S. 984 Before the Subcomm. on Int'l Trade of the Senate Comm. on Finance, 102d Cong., 1st Sess. 22, $27-28$ (1991) (statement of Robert J. Morris, Senior Vice President, U.S. Council on International Business); C. Foster Knight, Effects of International Trade and Investment-Selected Issues, 10 PAC. BASIN L.J. 212, 217-18 (1991). Industry representatives who downplay the impact of U.S. environmental regulation on competitiveness may fear that if it were widely accepted that U.S. industry were suffering serious disadvantages the most likely result would not be relaxation of U.S. requirements but imposition of countervailing tariffs on imports from countries with less stringent requirements and other trade-restraining measures that would jeopardize international trade.

36. See California Group Challenges Industry "Business Flight" Theory, CLEAN AIR REPORT, July 30, 1992, at 37 (California environmental group challenges industry claim that industrial flight to Mexico justifies scaling back clean air goals).

37. See Stephen M. Meyer, Environmentalism Doesn't Steal Jobs, N.Y. TIMES, Mar. 26, 1992, at A23.

38. See LeONARD, supra note 8, at 79; E.P.A. Likely to Relax Rules on Air Pollution, N.Y. TIMES, Mar. 3, 1983, at B13 [hereinafter EPA to Relax Rules]; David Lauter, Bush May Try To Revive Some Industry Controls; S\&Ls, Airlines, Workplace Could Face Tighter Regulations; Rules Might be Eased in Other Areas, L.A. TIMES, Feb. 5, 1989, § 1, at 1; Martin Tolchin \& Susan J. Tolchin, The Rush to Deregulate, N.Y. TIMES, Aug. 21, 1983, § 6, at 34.

39. See Thomas J. Schoenbaum, Free International Trade and Protection of the Environment: Irreconcilable Conflict?, 86 AM. J. INT'L L. 700, 723 (1992); Developments in the Law-International Environmental Law, 104 HARV. L. REV. 1484, 1610 (1991) [hereinafter International Environmental Law]. 
agreement or extraterritorial application of U.S. law, including measures to require operations by U.S. multinationals abroad to comply with U.S. environmental measures. ${ }^{40}$ This was the approach favored by the Carter Administration. ${ }^{41}$ Similarly, in order to appease environmentalists critical of NAFTA, the Bush Administration was forced to persuade the Mexican government to strengthen its environmental programs. ${ }^{42}$

A third approach, which offers something to both industry and environmental groups, is to eliminate the competitive advantage enjoyed by foreign producers through unilateral U.S. legislation aimed at their imports. One form of this approach is to ban the import of goods produced by processes that do not conform to the environmental requirements imposed on U.S. producers. ${ }^{43}$ For example, the U.S. banned imports of tuna caught on the high seas by fishing boats that failed to comply with U.S. restrictions on the incidental take of dolphin. ${ }^{44}$ The ban was designed both to promote environmental protection and to eliminate the competitive disadvantage suffered by U.S. fishing fleets that complied with such restrictions. ${ }^{45}$

Alternatively, it has been proposed that the U.S. impose duties on imports produced by processes that do not conform to U.S. regulatory standards; the amount of the duty would be based on production cost savings enjoyed by foreign producers as a result of their nations' less stringent standards. ${ }^{46}$ In order to make such duties consistent with international trade law, the exporting

40. See, e.g., Malissa Hathaway McKeith, The Environment and Free Trade: Meeting Halfway at the Mexican Border, 10 PAC. BASIN L.J. 183, 209-211 (1991) (urging extraterritorial application of U.S. environmental regulatory and liability laws to U.S. firms operating abroad).

41. See LEONARD, supra note 8 , at 77 .

42. See Nancy Dunne \& Damian Fraser, Environmentalists Start to Call Tune in US; Awareness of Green Issues is Forcing World Institutions to Clean Up Their Acts, FIN. TIMES, May 3, 1991, \$ I, at 7; President Bush Announces Three-Year Plan to Clean Up Pollution at U.S. Mexican Border, 1992 Int'1 Env't Daily (BNA), Feb. 27, 1992, available in LEXIS, Nexis Library, BNAIED File; US and Mexican Officials Unveil Border Plan, But Environmentalists Say It's Not Enough, 2 ENV'T WaTCH LATIN AMi, Mar. 1992, available in LEXIS, Nexis Library, NWLTRS File.

43. See John Whalley, The Interface Between Environmental and Trade Policies, 101 EcoN. J. 1S0, 187-88 (1991).

44. This ban was overturned by a GATT panel which found that restrictions on product imports based not on the environmental or health risks of the product itself, but on those of the processes by which it was produced, are illegal under GATT. See GATT Ruling, supra, note 20 . This decision has fueled concern by environmentalists that trade rules will be used to weaken environmental protection. For discussion of the decision, see Stewart, supra note 10 , at 1358-59.

45. See GATT Panel Hears Arguments on U.S.-Mexico Tuna Dispute, with Focus on Trade Obligations, 1992 Int'l Trade Daily (BNA), May 16, 1991, available in LEXTS, Nexis Library, BNAITD File; Mexico Says U.S. Tuna Ban is to Protect U.S. Industry, Defends Its Dolphin Protection Plan, Int'l Trade Rep. (BNA), June 19, 1991, available in LEXIS, Nexis Library, BNAITD File.

46. See generally Schoenbaum, supra note 39 , at $723 \&$ n.131 (discussing possibility of countervailing subsidies among GATT contracting parties in cases of noncompliance with accepted minimum environmental standards); The Freedom to be Dirtier Than the Rest, ECONOMIST, May 30, 1992, at 7, 11 [hereinafter Dirtier Than the Rest] (noting failed Senate proposal to impose special duties on foreign imports produced in countries with less strict environmental standards); Eliza Patterson, International Trade and the Environment: Institutional Solutions, 21 Envtl. L. Rep. (Envtl. L. Inst.) 10,599 \& n.34 (Oct. 1991) (noting possibility of governmental policies that would fight lax foreign environmental standards by imposing duties on foreign products benefiting from those lax standards). 
state's less stringent environmental requirements could be characterized as (1) an unlawful subsidy designed to lower its industry's production costs; ${ }^{47}$ (2) a violation of antidumping laws, because the total social costs borne by consumers in the producing state, including pollution as well as ordinary product costs, are greater than the costs charged consumers in the importing state ("ecodumping"); ${ }^{48}$ or (3) a form of unfair competition. ${ }^{49}$ These proposals would seek to tax the pollution embedded in product imports. Such unilateral U.S. measures, it is asserted, would create a regulatory "level playing field" and prod other nations to raise their standards. ${ }^{50}$

Most economists who have examined the relation between environmental regulation and international trade would probably reject the basic premises on which each of these three proposals rests. On the one hand, many economists doubt the dominant assumption that differences in national environmental measures have a significant impact on international competitiveness. They base this doubt on empirical studies that in most cases fail to find a strong correlation between the two variables. ${ }^{51}$ On the other hand, to the extent that differences in environmental measures do affect international competitiveness, economists tend to believe that this effect is beneficial and that measures to

47. For general discussion of the concept of "subsidy" in countervailing duty law, see Charles J. Goetz et al., The Meaning of "Subsidy" and "Injury" in the Countervailing Duty Law, 6 INT'L REV. L. \& ECON. 17 (1986). The potential equation of lax regulation or excessive pollution with subsidy is noted in Kenneth S. Komoroski, The Failure of Governments to Regulate Industry: A Subsidy Under the GATT?, 10 Hous. J. INT'L L. 189, 203 (1988); Warren F. Schwartz \& Eugene W. Harper, Jr., The Regulation of Subsidies Affecting International Trade, 70 MICH. L. REV. 831, 834 n.14 (1972); John Schanz et al., The Subsidization of Natural Resources in the United States, Cong. Res. Serv. 41-42 (Feb. 28, 1986); see also David A. Wirth, The International Trade Regime and the Municipal Law of Federal States: How Close a Fit?, 49 WASH. \& LEE L. REV. 1389, 1398-1400 (1992) (advocating countervailing duties based on the "Polluter Pays Principle" and the notion of cost internalization).

48. For a general discussion of the concept of dumping, see JACOB VINER, DUMPING: A PROBLEM IN INTERNATIONAL TRADE (1923). Ordinarily, dumping is the practice of charging lower prices to consumers in the importing state than those charged consumers in the exporting state. Ecodumping extends this concept to a situation where the cost of a product includes not only the price of the product but the social costs of the pollution created in manufacturing it. Because the social cost of producing a product is higher in a state with lower environmental process standards, an exporting state with lower standards than an importing state that manufactures comparable products is said to be engaged in ecodumping.

49. Legislation has been proposed specifically to include lax environmental standards in other nations as a form of unfair trade competition under section 301 of the Trade Act of 1974, 19 U.S.C. $\$ \$ 2101-2495$ (1988). See S. 2887, 101st Cong, 2d Sess. (1990); S. 2553, 101st Cong., 2d Sess. (1990); Majority of Senate Finance Committee Sponsor Trade Agreements Bill, INSIDE U.S. TRADE, Feb. 8, 1991, at 2.

50. See S. 984, 102d Cong., 1st Sess. (1990); Boren Bill Would Impose Countervailing Duty for Insufficient Foreign Pollution Controls, 1991 Int'l Trade Daily (BNA), May 7, 1991, available in LEXIS, Nexis Library, BNAITD File.

51. See, e.g., Christopher J. DUERKSEN, EnVIRONMENTAL REgulation of Industrial Plant Siting: How to MaKe IT WORK BetTer 56 (1983); CARl A. PasurKa, JR. \& Deborah VaughN Nestor, ENVIronmental Protection Agency, Trade EfFects of the 1990 Clean AIR ACt AMENDMENTS (1992); Patrick Low \& Alexander Yeats, Do "Dirty" Industries Migrate?, in WorLd BANK PAPERS, supra note 6, at 89; James A. Tobey, The Effects of Domestic Environmental Policies on Patterns of World Trade: An Empirical Analysis, 43 KYKLos, fasc. 2, 191, 194 (1990) (indicating pollution control expenditures have at most a small effect on production costs, export/import performance, and industrial location). But see Kalt, supra note 22, at 221, 241-246, 249-254, 257 (finding substantial trade effects from environmental policies). These and other studies are discussed in Section III(C), infra. 
prevent it are undesirable. ${ }^{52}$ Still others contest the widely-held assumption that, if differences in environmental measures affect competitiveness, the effect of more stringent measures is negative. These analysts argue that a nation's adoption of more stringent measures will enhance the overall productive efficiency of its industry and develop its capacity to compete in the growing international market for "green" technologies. ${ }^{53}$

The position taken by this Article does not track any of those described above. The Article argues that differences in environmental measures do pose a threat to the competitiveness of industries in nations such as the U.S. that have more stringent regulatory and liability laws. This threat, however, is not imminently so severe as to justify wholesale regulatory retrenchment like that advocated by the Reagan Administration. ${ }^{54}$ Nor is the solution simply to export U.S. regulatory standards to activities abroad, as the Carter Administration advocated. ${ }^{55}$ Unilateral measures to ban or tax imports of products produced by means that do not conform to U.S. environmental requirements are also undesirable from the viewpoint of both environmental and trade policy.

Instead, the U.S. should seek to reduce the excessive costs and burdens imposed by its exceptionally rigid, legalistic system of environmental law and administration. It should also redirect priorities in order to avoid requiring its industry to devote large resources to environmental problems that are relatively unimportant. While the Bush Administration took some steps in this direction, it gave insufficient attention to the desirability of international harmonization of standards, particularly where the adverse effects of environmental degradation extend beyond national borders. Nevertheless, differences in nations' stages of development and in their social, economic, and environmental circumstances make complete harmonization unattainable and even undesirable as a goal. ${ }^{56}$ The overall conclusions of the Article are that

52. See, e.g., LEONARD, supra note 8, at 56-64 (summarizing economists' views); Patrick Low \& Raed Safadi, Trade Policy and Pollution, in WORLD BANK PAPERS, supra note 6, at 29, 34 (discussed infra Section $\Pi(C)$ ); David Robertson, Trade and the Environment: Harmonization and Technical Standards, in WORLD BANK PAPERS, supra note 6, at 309, 320; Ingo Walter, International Economic Repercussions of Environmental Policy: An Economist's Perspective, in ENVIRONMENT AND TRADE 22, 44 (Seymour J. Rubin \& Thomas R. Graham eds., 1982); Dirtier Than The Rest, supra note 46, at 7 (summarizing memorandum by Lawrence Summers, Chief Economist, World Bank).

53. See infra notes 204-215 and accompanying text; Crane, supra note 34; John Hunt, Industry and the Environment: Rising Levels of Concern, FIN. TIMES, Mar. 13, 1991, at I; Jonathan Marshall, Environmental Damage Abroad, State Firms in Position to Clean Up, S.F. CHRoN., Jan. 30, 1991, at A1. Moreover, environmental measures do not simply impose costs. They also provide environmental, health, and safety benefits. In some instances, those benefits are economic. For example, reductions in air pollution can enhance agricultural output. See infra notes 111-115 and accompanying text.

54. See E.P.A. to Relax Rules, supra note 38; Lauter, supra note 38; Tolchin \& Tolchin, supra note 38; Douglas P. Wheeler, Why America Fell Asleep Over the Environment, WASH. POST, Sept. 11, 1988, at C1; Robert Sangeorge, Untitled, UPI, June 27, 1984, available in LEXIS, Nexis Library, UPI File.

55. See supra notes $40-41$ and accompanying text.

56. Contrast, for example, the OECD countries with the nations of Eastern Europe, the former Soviet Union, OPEC countries, and the nations in Asia, Africa, and South and Central America. It cannot be expected that the less developed of these nations could or should achieve OECD levels of environmental 
some differences in national measures are desirable and will in any event persist; that such differences may well impair to some degree the international competitiveness of industry in nations with more stringent standards; and that the appropriate response to these circumstances is to manage the potential conflicts between environmental and economic objectives in order to promote both of them.

In order to provide a conceptual framework for addressing the policy debate, Part II of this Article analyzes the relationship between national environmental regulations and international trade and competitiveness. Part III reviews the empirical literature on this relationship. Part IV evaluates the implications of the conceptual analysis and the empirical findings for the contemporary policy debate. This final Part advocates reformation-but not retrenchment-of the U.S. environmental regulatory system to promote environmental objectives, industrial efficiency, and competitiveness in the international arena. It also calls for increased international harmonization of national measures to deal with significant environmental externalities that transcend national borders. The Article, however, rejects harmonization merely for the purpose of reducing the potential competitiveness effects of different national standards.

\section{ENVIRONMENTAL PRocess Regulation, LIABILITy RULES, AND COMPETTTIVENESS: A CONCEPTUAL ANALYSIS}

Environmental regulations and liability rules differ among nations, often strikingly so. The differences are greatest between the developed and the developing nations, but there are also substantial variations within each of those vague but convenient groupings. ${ }^{57}$ This Part provides a conceptual analysis of three questions: What accounts for these differences in environmental laws? What are the potential effects of these differences on international competition and trade? Are these effects desirable?

protection immediately.

57. The developed/developing country distinction is an inevitably convenient but potentially misleading simplification. For example, the distinction does not clearly account for the nations of Eastern Europe and the former Soviet Union, the OPEC nations, or the "Asian Tigers." There are also wide differences among the developing nations of Africa, the Americas, and Asia. On the difficulty of distinguishing among developed and developing countries, see generally GERALD M. MEIER, LEADING ISSUES IN ECONOMIC DEVELOPMENT 5-15 (1989) (pointing out that definitions of "development" vary with policy goals). 


\section{A. Explaining Differences in Environmental Standards Among Nations}

\section{Differing Assimilative Capacities}

One general explanation for national differences in environmental regulations and liability rules is that they appropriately reflect differences in environmental, economic, and social circumstances.

Geographic, ecological, and demographic variations among nations affect the ability of different nations to assimilate pollution and other forms of natural resource exploitation. A nation with fast-running, short rivers, such as Britain, can assimilate a higher level of water pollution with less environmental harm than nations with long, slow-running rivers such as Germany or France. ${ }^{58}$ Nations with soils that are low in buffering capacity suffer greater damage from acid deposition than those with high buffering capacity. ${ }^{59}$ A large, sparsely-populated country will suffer fewer adverse health and environmental effects from a given level of pollution emissions than will a small, densely populated country.

Nations also differ in their existing levels of pollution and other forms of environmental resource use. For example, those with lower levels, other things being equal, will be better able to accommodate additional pollution than nations that already have high levels of pollution. This conclusion must, however, be qualified by noting that nations with relatively pristine environments may have a strong interest in preserving them; in such a nation, the marginal harm of an additional increment of pollution may be greater than in a nation already moderately polluted.

Social, cultural, and historical factors may lead different societies to attach more or less importance to environmental protection as opposed to expanding the supply of public and private goods and services. For example, even within Western European nations at comparable stages of economic development, there are striking differences in environmental orientation between nations such as Germany, Denmark, and the Netherlands on the one hand and France, Great Britain and Italy on the other. ${ }^{60}$

There are also differences in wealth among nations. Experience shows that societies treat environmental quality as a "luxury"; they demand relatively

58. David Vogel quotes a British official arguing against the proposed adoption by the European Community of uniform technology-based water pollution discharge limitations: "Italy economically benefits from the amount of sunshine that it receives each year. Why should not our industry be able to take similar advantage of our long coastline ... and rapidly flowing rivers?" DAVID VOGEL, NATIONAL STYLES OF REGULATION: ENVIRONMENTAL POLICY IN GREAT BRITAIN AND THE UNITED STATES 103 (1986).

59. See Linda G. Caleca, Canada Acid Rain Much Worse for Canadian Soils than Indiana Soils, UPI, Apr. 29, 1982, available in LEXIS, Nexis Library, UPI File; Sulfur Controls Edge Closer in Acid-Rain Debate; Evidence Builds Against Acid Deposition, ENGINEERING News-ReC., Oct. 4, 1984, at 52.

60. See David Vogel, Environmental Protection and the Creation of a Single European Market 7 (1992) (unpublished paper presented at 1992 Annual Meeting of American Political Science Ass'n, on file with author). 
more of it as income rises and needs for housing, food, and other "basics" are satisfied. ${ }^{61}$ Wealthier societies also tend to be better educated and therefore more cognizant of the importance of environmental protection. Thus, wealthier nations are more likely to choose to devote a higher percentage of their resources to environmental protection. Wealth and associated educational levels also affect nations' abilities to develop strong, capable administrative authorities to devise, implement, and enforce effective environmental protection measures. ${ }^{62}$

Finally, nations differ in their stage of economic development, which affects not only their wealth but also the composition of their productive output. While there is no "iron law" that produces a fixed, uniform pattern of economic development, most contemporary nations have moved from economies that are based primarily on agriculture, to a stage of intensive industrialization, and then to patterns in which service industries are increasingly important. ${ }^{63}$ Nations at the intermediate stage of intensive industrialization are likely to produce proportionately more pollution and other forms of environmental degradation in relation to GDP than nations whose economies depend primarily either on agriculture or services. ${ }^{64}$ It will accordingly be relatively more costly for such nations to achieve a given level of environmental quality than those in which industry constitutes a smaller percentage of output.

These several variables will mean that different nations will vary in their capacity to assimilate pollution and other adverse environmental effects of resource use. They will also differ in the extent to which citizens are willing to forgo public and private goods and services to prevent environmental degradation. Accordingly, the governments of different nations, each responsive to the welfare of its citizens, could justifiably adopt environmental requirements of quite different stringency. These requirements would appropriately reflect the effective assimilative capacity of the environment in each country. ${ }^{65}$

61. See, e.g., Radetzki, supra note 6, at 132-33.

62. One measure of enforcement levels is the funding for enforcement efforts. In 1991, the U.S. per capita budget of the Environmental Protection Agency was \$24.40; the Mexican per capita budget of the Mexican environmental agency (formerly SEDUE, now SEDESOL), was \$.48. The Mexican figure in 1989, however, was only \$.08. See Juanita Darlin et al., Can Mexico Clean Up its Act?, L.A. TIMES, Nov. 17, 1991, at A1 (citing Congressional Research Service data).

63. See generally COLIN ClARK, THE CONDITIONS OF ECONOMIC PROGRESS 492 (3d ed. 1957) (pointing out that as economies develop, employment declines in agriculture then in manufacturing); RONALD K. SHELP, BEYOND INDUSTRIALIZATION: ASCENDANCY OF THE GLOBAL SERVICE ECONOMY 80-81 (1981) (citing exceptions to general pattern of development).

64. Robert E.B. Lucas et al., Economic Development, Environmental Regulation and the International Migration of Toxic Industrial Pollution: 1960-88, in WORLD BANK PAPERS, supra note 6, at 67, 67-69.

65. See Judith M. Dean, Trade and the Environment: A Survey of the Literature, in WORLD BANK PAPERS, supra note 6, at 15, 15-16; see also James E. Krier, The Irrational National Air Quality Standards: Macro- and Micro-Mistakes, 22 UCLA L. REV. 323, 324-330 (1974) (criticizing uniform federal air quality standards for ignoring variations in costs and benefits of pollution control among states). 


\section{Political Failure}

The account above assumes that all governments are responsive to their citizens' welfare and values, but this clearly is not the case. To varying degrees in different nations, environmental policies reflect the nature of the government and the influence of dominant economic or political factions. Some governments may be corrupt, ${ }^{66}$ incompetent, shortsighted, or overly responsive to development interests. As a result, they may adopt inadequate laws and fail effectively to enforce them. Other governments, driven by symbolic politics and responsiveness to alliances between regulatory bureaucracies and ideological interest groups, might adopt excessively stringent requirements. ${ }^{67}$ Accordingly, differences among national environmental standards may to some extent be explained by different forms of "political failure."

\section{Externalities}

Externalities can also generate inadequate standards. Environmental process standards are likely to be less stringent when some of the adverse environmental effects of a process are imposed on other nations, for example through transboundary pollution. The nation in which the processes are located is likely to pay little or no attention to the interests of other nations, and accordingly, it will fail to adopt adequate requirements. For many years Britain did not control sulfur emissions from its power plants because most of the adverse effects were experienced in Scandinavia and elsewhere. ${ }^{68}$ Some nations may allow destruction of their tropical rain forests because most of their own citizens do not care greatly about preserving them, even though many people in other countries are extremely distressed by the disappearance of rare species and ecosystems. ${ }^{69}$ In such cases, nations will often fail to adopt appropriate environmental standards because of a political externality; the costs of more stringent standards will be borne by the nation adopting them, whereas a significant portion of the benefits will go to those in other countries.

66. See LEONARD, supra note 8 , at 226-29.

67. Jerry L. Mashaw, The Economics of Politics and the Understanding of Public Law, 65 CHI.KENT L. REV. 123, 132-33 (1989).

68. See Untitled, UPI, Sept. 11, 1986, available in LEXIS, Nexis Library, UPI File (article begins, "Britain, blamed for acid rain over Scandinavia . . . ."); Sandra Maler, Norway Protests to Britain Over Acid Rain, REUTERS N. EUR. SERVICE, Dec. 9, 1985, available in LEXIS, Europe Library, REUTERS File; Nordic Countries to Condemn U.K. Failure to Cut Pollution, ReuTERS N. EUR. SERvICE, Dec. 10, 1984, available in LEXIS, Europe Library, REUTERS File; Richard Wallis, Sweden Criticises Britain Over Acid Rain Pollution, REUTERS N. EUR. SERVICE, Mar. 4, 1985, available in LEXIS, Europe Library, REUTERS File.

69. See, e.g., David AdAmson, Defending the World: THE Politics and Diplomacy of the ENVIRONMENT, 90-104 (1990). 
A somewhat different form of externality problem is present in the case of the global commons, such as the atmosphere, the oceans, or Antarctica. Biological diversity might also be regarded as a form of global commons even though many biological resources are located within natural boundaries. All nations may benefit if each acted to protect the commons from despoliation, but no nation has an incentive to take such action. Each nation may, for example, benefit from measures to eliminate emissions of chlorofluorocarbons (CFC's) that destroy upper atmospheric ozone, causing an increase in cancercausing ultraviolet radiation at the earth's surface. ${ }^{70}$ Similarly, it may be in the mutual interest of all nations to limit whaling in order to prevent the extinction of whales. ${ }^{71}$ From the viewpoint of any one nation it may not, however, be rational to unilaterally limit CFC emissions or whaling because most of the benefits of such action would accrue to others while it would bear all of the costs. If this is true for each nation, no nation will adopt restrictions, even though all nations would be better off if each did. Under this "tragedy of the commons" scenario, no one will prevent the despoliation of the commons. $^{72}$

Even if the benefits to a nation of its action to protect the global commons exceeds its costs and the nation unilaterally adopts restrictions, ${ }^{73}$ other nations will not follow if their cost-benefit calculus of unilateral action remains negative. ${ }^{74}$ Moreover, countries that do not take measures to protect the environment can "free ride" by enjoying some of the benefits of the actions unilaterally taken by other countries without incurring any of the costs. This "'exploitation' of the great by the small"75 may explain some differences in national standards relating to the global commons.

70. See, e.g., Robert W. Hahn and Albert M. McGartland, The Political Economy of Instrument Choice: An Examination of the U.S. Role in Implementing the Montreal Protocol, 83 Nw. U. L. REV. 592, 595 (1989).

71. See, e.g., Anthony D'Amato \& Sudhir K. Chopra, Whales: Their Emerging Right to Life, 85 AM. J. INT'L. L. 21, 22 (1991).

72. A seminal discussion of the "tragedy of the commons" is found in Garret Hardin, The Tragedy of the Commons, 162 SCIENCE 1243, 1244 (1968).

73. A nation might engage in unilateral action if, for example, it is large, rich, and strongly committed to environmental protection.

74. The marginal cost of controls to another nation will remain the same, barring technological innovation resulting from the unilateral initiative. The marginal benefit of controls could theoretically increase or decrease, depending on the shape of the damage function. If, as seems likely in many cases, damages increase more than proportionately to emissions, the unilateral initiative will reduce the marginal benefits of action by others, making action by others less likely. If, for example, major sources of carbon emissions such as the U.S., the European Community, Brazil, Russia, and the Eastern European nations made heavy cuts in their emissions, the resulting reduction in the threat of climate change could reduce the incentives of other nations, such as China and India, to limit their emissions. For a discussion of the strategic conflicts among nations in connection with the negotiation of the Framework Convention on Climate Change, see Daniel Bodansky, The United Nations Framework Conventions on Climate Change-A Commentary, 18 YALE J. INT'L L. (forthcoming summer 1993).

75. The phrase is Mancur Olson's. See MANCUR OLSON, THE LOGIC OF COLlECTIVE ACTION: PUBLIC GOODS AND THE THEORY OF GROUPS 29 (1971). 
No single one of these three explanations-differences in assimilative capacity, political failure, and externalities-can account for all differences among national environmental measures; yet each plays a role. Untangling their relative explanatory power in particular circumstances involves difficult empirical and normative questions. The empirical issues include identifying and measuring the extent of differences in environmental, cultural, and economic circumstances that might account for variances in standards. The normative questions include issues such as the extent to which differences in circumstances might appropriately justify variances in standards, or the criteria for determining whether a government is responsive to the welfare and values of its citizens. The issue of externalities presents both types of questions. There is debate over the scientific question of whether local pollution or resource uses may have cumulative, adverse effects on regional or global ecosystems. Environmentalists tend to believe that such effects are significant. There is also debate over the extent to which developing countries should be obliged to preserve natural resources for the benefit of developed countries. As discussed below ${ }^{76}$ these empirical and normative difficulties bedevil the effort to develop national or international principles and measures to deal with trade, environment, and competitiveness.

\section{B. Effects of Differing National Environmental Requirements on Competitiveness}

Variations in the stringency of different nations' environmental measures have potentially important implications for international trade and investment. On standard economic assumptions, putting aside for the moment markets for "green" technologies created by environmental regulation and liability rules, industries in nations with higher assimilative capacity and less stringent environmental regulation and liability rules will face lower compliance costs and enjoy a comparative advantage in international product competition. ${ }^{77}$ New industrial facilities will have a tendency to locate in nations with lower compliance costs, until these nations' assimilative capacities decrease and compliance costs increase to the level of other nations. ${ }^{78}$ These are the essential features of what we may call the international market in comparative assimilative capacity. The actual extent of any such comparative advantage and locational adjustment is an empirical question that is addressed in Part III below.

In addition, the effects of different standards and liability rules on competitiveness depend not only on the rules' relative stringency but also on

76. See infra notes 335-349 and accompanying text.

77. See sources cited supra note 52 .

78. See id. 
the policy instruments and legal and administrative approaches chosen to implement these measures. A relatively rigid, legalistic command-and-control regulatory approach, like that used in the U.S., tends to drive up compliance costs. ${ }^{79}$ Nations with more flexible, less litigious approaches can achieve the same basic level of environmental protection at significantly less cost. ${ }^{80}$ Nations adopting regulatory approaches that enable industry to meet environmental goals at lower cost thus enjoy a comparative advantage over other nations.

\section{Desirability of International Competition in Assimilative Capacity}

Let us suppose, subject to the qualifications noted, that the international market in comparative assimilative capacity operates as described. Is such a market desirable? Or should states adopt uniform standards, unilaterally impose countervailing duties, or take other measures against product imports from states with less stringent process standards? Should international businesses' investment decisions be regulated in order to limit capital mobility? Most economists would probably applaud the market and oppose such measures, claiming that they would reduce social welfare. ${ }^{81}$ Economists would argue that investment in polluting industry should flow to nations with lower standards and greater assimilative capacity. This flow of investment benefits the residents of these nations, who place a higher priority on expanding the output of public and private goods and services or can assimilate pollution with less environmental damage. It also benefits residents of nations with higher standards and lower assimilative capacity, who would suffer greater welfare loss if polluting industries were located in their country. This beneficial flow of investment is driven by variations in relative competitive advantage attributable to the differences in national standards..$^{82}$ Adoption of uniform standards would lead to inappropriately high standards in nations with higher assimilative capacity, forcing them to devote too few resources to non-

79. See Bruce A. Ackerman \& Richard B. Stewart, Reforming Environmental Law: The Democratic Case for Market Incentives, 13 CoLUM. J. ENvTL. L. 171, 173-75 (1988). Under a command-and-control approach, government regulators specify the control technology or the maximum levels of pollution or hazard that each product, production unit, emissions or discharge source, waste treatment, waste storage, or waste disposal facility must meet. Other approaches, such as market-based incentives or contractual arrangements, allow sources much more flexibility to take into account variances in costs, production processes, and individual circumstances relevant to environmental protection goals. See infra Part IV(B). The U.S. has largely followed a highly detailed command-and-control approach. Because of the large number and many different types of products and processes subject to regulation, this approach produces an enormous bulk of highly complex regulatory law. For example, the published collection of general federal regulations relating to environmental protection programs administered by the EPA consumes 15 volumes in the Code of Federal Regulations. See 40 C.F.R. $\$ 1-799$ (1992).

80. See VOGEL, supra note 58 , at 23-24.

81. See, e.g., sources cited supra note 52; Patrick Low and Raed Safadi, Trade Policy and Pollution, in WORLD BANK PAPERS, supra note 6, at 29, 34.

82. See Martin C. McGuire, Regulation, Factor Rewards, and International Trade, 17 J. PUB. ECON. 335,336 (1982). 
environmental goods and services which they would otherwise prefer. It might also lead to inappropriately low standards in other nations. Unilateral measures would reduce welfare by restraining trade without producing compensating benefits. $^{83}$

Those concerned with environmental protection and the impact of different national standards on U.S. competitiveness make two attacks on these conclusions. One attack questions whether the international market in assimilative capacity operates in the welfare-maximizing fashion described. It has been claimed that competition among nations for industry is a form of Prisoner's Dilemma. ${ }^{84}$ Each nation, acting independently, fears that other nations will adopt lax environmental requirements, and that it will therefore suffer serious competitive disadvantage by adopting the more stringent requirements that it prefers. Since each nation reasons in the same way, all adopt less stringent requirements than they would prefer individually. This is the "race to the bottom." 85 More colorful accounts include industry efforts to play one nation off another and engage in "blackmail."

The response to this criticism is that there is no reason to suppose that international competition for comparative advantage will lead nations to adopt inappropriately low environmental standards. In a purely domestic context, a government must weigh the benefits of environmental protection against the cost of forgoing other goods and services that could be produced by the resources devoted to environmental protection. In the international context, those costs may also include reduced competitiveness in the world market, a cost set by the existing levels of environmental requirements throughout the world. Each nation will weigh this cost against the benefits of enhanced

83. This economic view of national environmental standards, trade, and investment is set forth more fully in LEONARD, supra note 8, at 54-82.

84. See International Environmental Law, supra note 39, at 1554 n.20. In the classic Prisoners' Dilemma, two prisoners are separately interrogated by the authorities, who attempt to extract confessions from each implicating the other. If both are silent, each will go free. If both confess, each will get a moderate sentence. If one confesses and the other does not, the former will get a light sentence and the latter a heavy sentence. Accordingly, both prisoners would be best off if each remains silent, but each fears that the other will confess. To avoid the danger of the heavy sentence that would follow from the other's confession, each confesses and incurs a moderate sentence. The prisoners are unable to reach their preferred outcome (total silence) because they are unable to communicate and reach a binding agreement. See $\mathrm{R}$. DUNCAN LUCE \& HOWARD RAIFF, GAMES AND DECISIONS: INTRODUCTION AND CRITICAL SURVEY 94-97 (1957).

As adapted to the situation of different nations' environmental regulations, the model claims that each nation will not adopt the standard that it prefers because it fears that the other will adopt a lower standard in order to gain competitive advantage. Since each nation reasons in the same way, both will end up with lower standards than they prefer. They are unable to coordinate their choices because of the difficulty in reaching a binding agreement that can be enforced.

85. See Richard L. Revesz, Rehabilitating Interstate Competition: Rethinking the "Race to the Bottom" Rationale for Federal Environmental Regulation, 68 N.Y.U. L. REV. (forthcoming Apr. 1993) (discussing issue in context of competition for industry among states in the U.S.).

86. See David E. Anderson, Untitled, UPI, Jan. 15, 1983, available in LEXIS, Nexis Library, UPI File; Richard B. McKenzie, A Threat of Industrial Blackmail, HeRITAGE FouND. REP., Dec. 30, 1982, No. 237, available in LEXIS, Nexis Library, HFRPTS File. 
environmental protection, which are a function of its assimilative capacity. Each nation will achieve its own balance between cost and benefit. As Professor Richard Revesz forcefully argues, there is no Prisoner's Dilemma and no race to the bottom. ${ }^{87}$

There are nonetheless ways in which a "race to the bottom" might occur. One possibility is that national political systems are myopic. The government of Nation $A$ may lower its standards in order to gain competitive advantage, not foreseeing that $B$ may reduce its standards in response. When $B$ matches its reduction, $A$ may reduce its standards still further in the false expectation of securing a permanent advantage. Such extreme myopia, which might produce a never-ending downward spiral in standards, seems highly implausible. $^{88}$

A more realistic possibility is that $A$ is uncertain about the exact value that $B$ 's political system places on environmental protection and how $B$ 's government will respond to $A$ 's choice of standard, and vice-versa. If each nation's choice of standards depends on those chosen by other nations, if each is uncertain as to what choices others will make, and if each is unsure how others will respond to its choices, it is possible that each nation might indeed adopt lower standards. For example, assume two nations, $A$ and $B$, and three relevant levels of environmental protection, 1, 2, and 3 (with 3 representing the highest level of protection). Because $B$ is wealthier than $A$, it prefers a higher level of environmental protection than $A$ and is willing to incur the competitive disadvantage involved, provided that the difference between its level and $A$ 's is not greater than 1. A wants to maintain a competitive advantage as against $B$, but will be satisfied with that provided by a difference in environmental levels of 1 . Within these constraints, $B$ would prefer level 3 , and $A$ would prefer level 2. Each, however, is uncertain of the other's priorities and the level that it will adopt. $A$ is equally uncertain whether $B$ will choose 1,2 , or 3. Because 2 is the average expected level that $B$ will adopt, $A$ adopts level 1 . $B$, in response, adopts level 2 . Both end up with lower levels of environmental quality than they would prefer.

Whether this is a realistic model of national environmental decisionmaking is, however, subject to question. For many environmental problems, nations do not find themselves at ground zero; each nation has already chosen standards and may be subject to internal and external constraints in changing them. ${ }^{89}$

87. See Revesz, supra note 85 . Put in somewhat different terms, it may be conceded that the decisions of one nation about environmental standards create externalities for other nations by reducing or enhancing competitive effects. These are pecuniary externalities, however, which should not produce market failures.

88. Because of the lag time in $B$ 's response, it is more plausible that $A$ might cut its standards in order to obtain a temporary competitive advantage over $B$. This temporary advantage could still not suffice to divert new investment to $A$, because of both the lag time in investment decisions and the reluctance of multinational enterprises to invest in a nation to secure the mere fleeting advantages of temporarily lower environmental standards.

89. A "ground zero" model may, however, be appropriate for newly discovered environmental 
Further, the large number of nations may restrict the scope for strategic interdependency. Finally, the priority that other nations place on environmental protection and their likely responses to changes in standards by others may not be as uncertain as in the example. ${ }^{90}$ Despite these and other questions, the example suggests that the risk of a "race toward the bottom" cannot be entirely ruled out.

The second attack on the desirability of international competition in comparative assimilative capacity invokes political failures and externalities which, for reasons explained earlier, may lead some nations to adopt seriously inadequate standards. When this occurs, the competitive disadvantage to other nations of maintaining more stringent standards increases, causing these other nations to adopt laxer requirements. This scenario provides an alternative account of the "race toward the bottom."

Many environmentalists believe that everything is connected to everything else, and that the regional and global environmental externalities generated by local activities are pervasive and powerfully destructive. If this is the case, this Article's premise that environmental policy is presumptively a national matter is questionable. Far-reaching regional or international agreements or authorities would be necessary to deal with systematic and compelling externalities. Such externalities would also reduce the importance of, and therefore the need to accommodate, national differences in ecological conditions and values that would otherwise justify substantial differences in national standards. They would undercut economists' argument for an international market in comparative assimilative capacity. If the adverse effects of local pollution and other resource uses are indeed global, pervasive, and serious, then a worldwide imperative of environmental protection may indeed trump Ricardo.

This view underlies Professor Edith Brown Weiss' endorsement of "sustainable development" as a common obligation of all nations and

problems, such as global climate change.

90. Even if uncertainty is reduced, however, inappropriately low standards may still result if other factors, such as systematic predictive error or risk aversion, come into play. For example, politicians in $A$ may know that $B$ places a relatively high value on environmental protection and would in no event choose Level 1. However, they might erroneously predict that $B$ was more likely to adopt Level 2 than Level 3 because they tend systematically to undervalue the political power of environmental as opposed to economic considerations. Or $A$ 's politicians, in the face of uncertainty, may be more averse to the risk of failing to maintain economic advantage and suffering loss of industry and unemployment than the risk of failing to achieve the level of environmental protection which $A$ 's citizens prefer, and therefore adopt level 1. One would, however, have to provide plausible reasons why such systematic predictive errors or patterns of risk aversion might occur.

Professor Revesz suggests an entirely different reason why nations might systematically adopt unduly low environmental standards. For political reasons, governments may be compelled to impose taxes on mobile capital in order to fund government-provided goods, services, and transfer payments. Such taxes, however, would lead mobile capital to fund investments in other jurisdictions. In order to offset this effect, governments may reduce environmental, health, or safety regulations below the otherwise appropriate level. See Revesz, supra note 85.

91. See supra notes 84-86 and accompanying text. 
peoples. ${ }^{92}$ Thus far, however, science has established relatively few acute environmental externalities of broad scope; these include stratospheric ozone depletion, atmospheric buildup of greenhouse gasses, loss of biodiversity, and instances of regional air or water pollution problems..$^{93}$ In addition, interests of national sovereignty do not easily yield, and differences in wealth and societal values will continue to produce significant variations in the priority accorded environmental protection in different nations. In these circumstances, uniform environmental standards will in most instances be neither appropriate nor feasible. ${ }^{94}$ Steps towards harmonization should focus on the most significant externalities. ${ }^{95}$

Global economic rivalry introduces a further complication. Environmental externalities would exist even in the absence of trade, but trade, capital mobility, and the resultant struggle by businesses and nations for competitive edge make environmental standards a possible element of comparative advantage. This struggle could hinder effects to harmonize national standards. At the same time, the struggle introduces the threat of a "race to the bottom" in environmental standards, giving environmentalists another reason to promote harmonization. The next Part examines how more rigorous empirical studies might illuminate questions on the effect of differing environmental standards between nations. Policy implications are assessed more fully in Part IV.

\section{PROCESS REgULATION AND INTERNATIONAL COMPETITIVENESS: EMPIRICAL STUDIES}

To what extent do national differences in environmental process regulation and liability affect the international competitiveness of nations' industries? Whether one regards international competition in comparative assimilative capacity as benign or destructive, the market model predicts that it will affect the costs, and therefore the competitiveness, of the affected industry. What is the significance of such effects? The answer determines whether disparities in national process requirements deserve attention from domestic and international decisionmakers. If the effects are nonexistent or trivial, then energy should be directed toward other issues.

The empirical studies of the competitive impact of different national environmental standards attempt to correlate the costs to industry of different

92. See Weiss, supra note 4, at $2123,2128-33$. A similar perspective underlies Dean Alfred Aman's discussion of the need for a "global discourse" to develop environmental regulation. See Aman, supra note 3 , at $2111-16$.

93. For a forceful argument that problems such as global climate change are far less important than immediate, local environmental health problems in developing countries, see Wilfred Beckerman, Economic Growth and the Environment: Whose Growth? Whose Environment?, 20 WORLD DEV. 481, 482 (1992).

94. See infra Section IV(C) (arguing for limited intemational harmonization of standards).

95. See Stewart, supra note 10, at 1360, 1366 (arguing for need to limit trade restrictions aimed at environmental externalities to cases where extemalities are significant.) 
nations' environmental standards with various measures of competitiveness, including productivity, trade performance, and industrial location. ${ }^{96}$ Before reviewing these studies, this Part outlines the two basic types of difficulties involved in measuring the costs of environmental requirements and their competitive effects. First, there are inherent difficulties in measuring the costs of environmental regulations, even within a single country. Second, there are special problems in attempting to measure, on a comparative basis, the relation between environmental regulations and compliance costs in different countries. While such difficulties do not mean that empirical studies can teach us nothing, understanding their limitations is essential in evaluating the studies' findings.

\section{A. Inherent Difficulties in Measuring the Costs of Environmental Regulations and Liability Rules}

By far the most extensive literature on regulatory compliance costs deals with regulatory costs in the U.S. Researchers generally equate such costs with industry's outlays to comply with regulatory requirements. These outlays include: 1) investment in capital plant and equipment; 2) increased operating costs; 3 ) research and development expenditures to reduce the costs of meeting present and anticipated future regulatory requirements; and 4) administrative and legal costs. Almost all studies focus on the first two items. ${ }^{97}$ Even here there are problems of cost measurement and allocation. ${ }^{98}$ What percentage of the investment in a new, low-polluting manufacturing process should be allocated to pollution control requirements, and what percentage to investment in economically efficient new plants? Should the costs of decommissioning aging coke ovens be attributed to environmental regulatory requirements, or to the equipment's economic obsolescence?

Studies of investment outlays and increased operating costs attributable to U.S. environmental regulation show compliance expenditures that are large in absolute terms and growing quite rapidly. For example, a 1990 EPA study found that, for pollution control alone, annual compliance outlays (in 1990 dollars) had risen from $\$ 30$ billion in 1972 ( $.9 \%$ of GNP) to $\$ 115$ billion in 1990 ( $2.1 \%$ of GNP), and were estimated to grow to $\$ 185$ billion ( $2.8 \%$ of GNP) by 2000 , assuming full implementation of existing law. ${ }^{99}$ Yet such

96. See infra Part III(C).

97. See, e.g., studies cited supra note 51 and infra notes 121, 123-124, 146.

98. See, e.g., CONGRESSIONAL BUDGET OfFICE, ENVIRONMENTAL REGULATION AND ECONOMIC EFFICIENCY 49-58 (1985); Aman, supra note 3, at 2109 n.5 (detailing additional problems in measuring environmental compliance costs).

99. ENVIRONMENTAL PROTECTION AgENCY, ENVIRONMENTAL INVESTMENTS: THE COST OF A CleAN ENVIRONMENT 2-1 (1990) [hereinafter COST OF A CLEAN ENVIRONMENT]. EPA defines the "costs of full implementation" as "those that would arise from full attainment or full compliance with those existing laws, regulations, and programs for which the attainment deadline has passed but for which there was 
costs represent an average of only $.54 \%$ of total production costs for industry as a whole and from $1 \%$ to $3 \%$ for the most heavily regulated industries. ${ }^{100}$

Studies of industry-by-industry compliance outlays, however, represent a highly incomplete accounting of the costs of environmental regulation and liability rules. Such reports fail to consider many other relevant costs, as well as benefits, and may therefore provide a misleading picture of the total net cost of environmental measures.

\section{The Invisible Costs of Investments and Innovations Forgone}

Studies of the costs of environmental laws generally do not attempt to measure the opportunity costs imposed by regulatory constraints, delays, and uncertainties, and by the risks of damage liability. ${ }^{101}$ Regulation, particularly of the highly legalized command-and-control variety favored in the U.S., may foreclose firms' adoption of economically productive processes and products. Litigation-oriented command regulation also involves considerable uncertainty and delay. Firms seeking to market new products or increase manufacturing capacity are often unsure whether or when they will be able to obtain the necessary regulatory approvals. Such delays and uncertainties reduce projected return on investment, thereby discouraging innovation and turnover of capital stock. The tendency in command systems to impose disproportionately more stringent controls on new processes and products has similar effects. ${ }^{102}$

The reason that empirical studies ignore these opportunity costs is that they are inherently difficult to measure systematically. One hears anecdotal accounts from industry representatives about plants that were not built because of regulatory requirements or uncertainties, or of plants that were downsized, sacrificing economies of scale, in order to avoid regulatory thresholds. ${ }^{103}$

substantially less than full attainment by 1987." Id. at $1-5$. With the exception of land-based waste regulation, these costs include only compliance outlays required by federal law. They do not include the costs of state air and water pollution control regulation that is more stringent than federal regulation.

100. Patrick Low, Trade Measures and Environmental Quality: The Implications for Mexico's Exports, in WORLD BANK PAPERS, supra note 6, at 105, 106-07.

101. See generally Richard B. Stewart, Regulation, Innovation, and Administrative Law: A Conceptual Framewark, 69 CAL. L. REV. 1256, 1294 (1981).

102. For example, the Clean Air Act imposes special permitting and review requirements on new sources whose emissions exceed a certain threshold. Clean Air Act, 42 U.S.C. $\S \S 7475,7479$ (1) (1988 \& Supp. 1992) (Prevention of Significant Deterioration controls on new sources of air pollution apply to "major emitting facilities ... which emit, or have the potential to emit, one hundred tons per year or more of [regulated] pollutant[s]. ..."). For a discussion of the effects of these disproportionate controls on new processes, see Peter Huber, The Old-New Division in Risk Regulation, 69 VA. L. REV. 1025, 1026-28 (1983); Paul R. Portney, Air Pollution Policy, in Public Policies for Environmental Protection, 27, 79 (Paul R. Portney ed., 1990) [hereinafter Public PoliCiEs]; Stewart, supra note 101, at 1269-71.

103. For example, corporate officials have told this author that, given air pollution control and other environmental requirements and liabilities, it would be infeasible to build a new copper smelter in the U.S., and that U.S. firms will therefore locate new smelting capacity abroad. The author has been similarly informed that a steel galvanizing line at a steel plant was reconfigured solely in order to bring emissions just below the level that would trigger new source review under the Clean Air Act. 
Such reports, however, are potentially self-serving and do not provide the basis for an objective, reliable measure of the economic benefits forgone as a result of environmental requirements. It would be extraordinarily difficult to identify and quantify, on an aggregate basis, the amount of productive new economic activity that did not occur but would have been undertaken under a different regulatory regime, much less to compare the extent of such effects under the regulatory and legal systems of different nations.

Furthermore, studies of the costs of environmental regulation focus almost exclusively on administrative regulations rather than liability rules. While some studies consider the transaction costs associated with litigating CERCLA (Superfund) claims for toxic waste cleanup, ${ }^{104}$ none examine the costs of preventive measures taken to avoid environmental liabilities, ${ }^{105}$ or the costs associated with decisions not to undertake new projects because of liability risks. These costs may be particularly significant in the U.S., where the legal system creates large liabilities for toxic waste cleanup, natural resource damages, and personal injuries. ${ }^{106}$ In addition, expanding U.S. environmental, health, and safety liabilities threaten the development of beneficial new products. ${ }^{107}$

Despite the difficulties in measuring the costs of investments and innovations forgone as a result of environmental laws, we should not disregard such significant costs. One can make qualitative judgments about aspects of legal and regulatory systems that are likely to affect the magnitude of such costs, and on that basis make a comparative assessment of the extent to which different legal and regulatory systems are likely to generate opportunity costs. One should also bear in mind that the failure of studies to consider these invisible costs means that their findings understate the total costs of environmental requirements. This understatement is likely to be significantly higher in the U.S. than in other countries because of its unique and farreaching environmental liability rules, its extensive use of highly detailed formal regulation, and the prevalence of court litigation. These characteristics increase investment risk and result in significant regulatory constraints and delays. ${ }^{108}$ In other industrialized countries, regulation is less formal and

104. See Jan P. Acton et al., Superfund and Transaction Costs: The ExPERIENCes of INSURERS AND VERY LAKGE INDUSTRIAL FIRMS, viii, x-xiv (1992).

105. Even when preventive measures can be identified, there may be problems of cost allocation. To what extent are the costs of minimizing and managing toxic wastes attributable to regulatory requirements like those imposed by Resource Conservation and Recovery Act (RCRA), and to what extent are such costs attributable to the threat of liability under the common law or statutes such as the Comprehensive Environmental Response, Compensation, and Liability Act (CERCLA)?

106. See W. Kip Viscusi, Product and Occupational Liability, 5 J. ECON. PersP., Summer 1991, at 71, 71-77.

107. See Peter Huber, Safety and the Second Best: The Hazards of Public Risk Management in the Courts, 85 ColuM. L. REV. 277, 278, 309-11 (1985).

108. See Stewart, supra note 101, at 1283-84. 
litigation far more infrequent. ${ }^{109}$ Comparative studies of regulatory costs thus omit consideration of an important category of costs that disproportionately disadvantage U.S. industry.

\section{The Benefits of Environmental Regulation}

Studies of the costs to industry of environmental measures generally fail to consider the economic benefits that industry may gain from regulation. Many of the benefits of environmental regulation are nonpecuniary-the enjoyment of clean air or a pristine environment, for example. These benefits do not appear as national income accounts, but can be significant. Because productivity figures are based on national income accounts, they ignore the contributions that government environmental regulatory programs make to national well-being. While these programs tend to reduce measured productivity, they may, if successful, increase total welfare when nonpecuniary benefits are taken into account. ${ }^{10}$ For these reasons, competitiveness concerns driven solely by measured productivity are shortsighted.

Regulation may also confer pecuniary benefits, some of which accrue to firms, reduce production costs, or enhance factor productivity. For example, reduced water pollution will lower the costs incurred in treating water by industries who use it in their production processes. ${ }^{11}$ Air pollution controls can reduce crop injury and boost agricultural output. ${ }^{112}$ A potentially important pecuniary benefit of environmental protection measures is a healthier and therefore more productive workforce. The shocking environmental conditions in certain parts of eastern Europe and the former Soviet Union are reported to have severely eroded the productivity of workers. ${ }^{113}$ Environmental benefits that reduce costs and increase productivity enhance a nation's competitiveness. ${ }^{114}$ Thus, analysis of the effects of environmental

109. See infra notes $256-265$ and accompanying text.

110. See Robert Repetto, Environmental Productivity and Why It is So Important, CHALlenge, September-October $1990,33,38$. Repetto found that environmental regulations had reduced measured productivity in the electric utility sector. He then estimated, based on empirical studies, dollar values for the environmental benefits produced by these regulatory programs, and added these benefits to the measured output of electric utilities. Repetto found that, under this enhanced measure of output, regulations had increased the total productivity of electric utilities.

111. A. MYRICK FREEMAN III, AIR AND WATER POLLUTION CONTROL: A BENEFIT-COST ASSESSMENT 169-70 (1982).

112. See id. at 86-87.

113. Anthony Cortese, Financing the Environment Forum, The Cost of Cleaning Up: The Scope of the Problem, INSTITUTIONAL INVESTOR, July 1990, at 3; see also Jessica Mathews, The Union of Soviet Socialist Pollution, WASH. POST, Mar. 22, 1991, at A25.

114. Even benefits that consist merely of enhanced environmental amenity, such as the aesthetic enjoyment of clean air or pristine woodland, might lower production costs. Where labor markets are competitive, labor is highly mobile. Since members of the work force both value environmental amenity and know about the levels of amenity provided in different nations, workers should in theory be willing to accept a lower wage in nations with higher environmental amenities. These conditions, however, are 
regulation on competitiveness should in principle consider pecuniary benefits as well as costs in order to determine net costs.

There have been a number of studies estimating the pecuniary benefits of environmental regulation in the U.S.: enhanced crop yields, reduced soiling, and the like. ${ }^{115}$ It appears that there has been no effort to examine the competitiveness implications of such benefits, perhaps because they generally accrue to sectors other than those regulated. Economic benefit studies of regulation in other countries are sparse. Under these circumstances, one can only conclude that in this respect studies overstate the costs of regulation. The extent of the error will depend largely on the industry in question. More stringent regulations will produce greater benefits (including pecuniary benefits) and impose higher costs, but not necessarily in the same proportion. ${ }^{116}$

\section{The Indirect Effects of Industry Regulation on the Economy as a Whole}

All but a few studies of environmental costs look only at outlays by the industries subject to regulation. ${ }^{117}$ They do not consider the ripple effects of such costs on other sectors of the economy or on overall investment, labor supply, consumption, and the other dynamic underpinnings of the macroeconomy. These second- and third-order effects can be addressed, at the cost of significantly added complexity and expense, through input/output and general equilibrium analyses. When these indirect effects are analyzed, the net costs of regulation to society may be either greater or less than the direct compliance outlays of the regulated industry.

For example, Hazilla and Kopp studied the costs of federal air and water pollution control during the 1980 's. ${ }^{118}$ They found that costs for 1981, which EPA estimated at $\$ 42.5$ billion based on engineering studies of compliance outlays by regulated firms, were only $\$ 28$ billion when indirect effects on society as a whole were analyzed, including the substitution effects that result in fewer purchases and thus reduced output of products whose price has

rarely realized in the international context.

115. See Freeman, supra note 111, at 86-91 (1982); Paul R. Portney, Air Pollution Policy, in Public POLICIES, supra note 102 , at 27,55 .

116. More stringent regulations are likely to produce greater benefits (including pecuniary benefits) as well as higher costs. If benefits (including pecuniary benefits) were always proportionate to costs, then the ratio of gross regulatory costs between country $A$ and country $B$ would be the same as the ratio of net regulatory costs (costs minus pecuniary benefits). In that event, the failure to consider pecuniary benefits would not affect the comparative analysis of regulatory costs between two countries. Nevertheless, some nations' regulatory systems may yield higher benefits for a given level of costs than others' systems. See infra notes 131-132 and accompanying text. To the extent that this occurs, the failure to consider pecuniary benefits will skew comparative analysis.

117. See studies cited supra note 51 and infra notes $121,123-124,146$.

118. Michael Hazilla \& Raymond J. Kopp, Social Cost of Environmental Quality Regulations: A General Equilibrium Analysis, 98 J. POL. ECON. 853 (1990). 
increased as a result of regulation. ${ }^{119}$ On the other hand, when intertemporal dynamic effects were taken into account, they found that total industry compliance costs of $\$ 525.8$ billion for the period 1981-1990 translated into a $\$ 977$ billion cost for society as a whole, equivalent to a $5.85 \%$ decline in GNP. ${ }^{120}$ Consideration of indirect effects not only alters the magnitude of regulatory costs but also their incidence, further complicating the analysis of effects on the competitiveness of different industries. ${ }^{121}$

\section{B. Special Problems in Comparative Studies}

Several comparative studies seek to determine the differences in compliance costs attributable to variations in environmental regulations and liability rules among different countries. For example, a 1979 study by the Organization for Economic Cooperation and Development (OECD) found that private sector spending on pollution control amounted to $1 \%$ of GDP in Japan, $0.44 \%$ in the U.S., and between $0.34 \%$ and $0.28 \%$ in leading Western European countries. ${ }^{122}$ An EPA study found that in 1985 the U.S. was spending $1.44 \%$ of GDP on pollution control, slightly less than Germany, and appreciably more than five other Western European nations. ${ }^{123}$ A 1991 OECD study, based on mid-1980's data, found that pollution control expenditures were $1.47 \%$ of GDP in the U.S., $1.52 \%$ in Germany, $1.25 \%$ in the U.K., and $.86 \%$ in France. ${ }^{124}$ The figure for Japan was $1.24 \%$, but this omitted current private sector expenditures, and was thus a significant understatement. ${ }^{125}$ These data indicate that the two most important competitors of the U.S., Japan and Germany, spend as much or more on pollution controls than we do, while other OECD countries spend appreciably less. A 1990 Resources for the Future study reviewed available data on the

119. Id. at 865 .

120. Id. at 865-67 \& tbls. 2 \& 3. Hahn and Hopkins estimate that the indirect costs of regulation added a further $50 \%$ to the $\$ 109$ billion cost of pollution control compliance outlays in 1990. Robert W. Hahn \& Thomas D. Hopkins, Regulation/Deregulation: Looking Backward, Looking Fonward, AMERICAN ENTERPRISE, July-Aug. 1992, at 70, 74.

121. See, e.g., OECD, THE MACRO-ECONOMIC IMPACT OF ENVIRONMENTAL EXPENDITURE 16-17, 34 (1985).

122. OECD, THE STATE OF THE ENVIRONMENT IN OECD MEMBER COUNTRIES $134 \&$ tbl. 19 (1979).

123. COST OF A CLEAN ENVIRONMENT, supra note 99, at 4-8, Fig. 4-8; see also ENVIRONMENTAL PROTECTION AGENCY, REPORT TO THE PRESIDENT ON THE 90-DAY REVIEW OF REGULATIONS 18 (1992).

124. OECD ENVIRONMENTAL DATA, DONNEES OCDE SUR L'ENVIRONMENT, COMPENDIUM 1991, 274275 (1991).

125. Id. at 274-275. Pollution abatement control expenditures represented $2.76 \%$ of total national investment in the U.S., $2.97 \%$ in Japan, $3.09 \%$ in Germany, and $1.22 \%$ in France. In the U.S., however, the private sector has a larger proportion of expenditures than in other nations, which rely more on public sector spending. For example, in the U.S. private sector expenditures were $.86 \%$ of GDP, while public sector expenditures were $.60 \%$. The comparable figures for Germany were $.74 \%$ and $.78 \%$; for the U.K., $.62 \%$ for both; and for France, $.30 \%$ and $.56 \%$. Id. at 275 . This difference could cause greater adverse competitiveness effects on heavily regulated U.S. industries. Nonetheless, the higher public sector expenditures outside the U.S. may reflect the public ownership of electric utilities and other industries in many nations. 
relative stringency of environmental standards in OECD countries. It found that standards for air and water pollution and hazardous wastes were roughly comparable in the various nations. The significant exception was the U.S. system of sweeping, retroactive liability for hazardous waste cleanup, which is causing rapid growth in expenditures and has no counterpart in other nations. ${ }^{126}$ No study, however, has systematically correlated differences in expenditures with differences either in the stringency of environmental standards or in environmental quality. Any efforts to do so would encounter a number of special problems presented by comparative national studies, as outlined below.

\section{Obsolescence of Data}

There are inevitable lags in reporting by industry of data about compliance costs, in the collection, processing, and publication of such data by government and other agencies, and in the eventual analysis of such data by scholars. ${ }^{127}$ In the meantime there may have been important changes in different nations' environmental policies and in the global competitive situation. The problem of obsolescent data is a substantial one even in the context of a single country study. It is especially severe in the case of comparative studies because of the difficulty in assembling data from many different nations and the problems caused by data collected and published on different bases from one country to the next. As a result, almost all of the comparative studies that exist are based on data from the mid-1970's, although there is also some data from the mid1980's on pollution control expenditures. There have been many subsequent changes that would affect comparative analysis. For example, the U.S. has adopted unique sweeping programs of toxic waste clean-up liability. ${ }^{128}$ These programs, estimated to cost as much as $\$ 420$ billion, ${ }^{129}$ have only begun to be fully implemented. Accordingly, their effects would not be reflected in existing studies.

\section{Different Regulatory and Enforcement Systems}

The ultimate subject of inquiry in comparative studies is the extent to which variations in the stringency of environmental standards in different

126. RAYMOND KOPP ET AL., INTERNATIONAL COMPARISONS OF ENVIRONMENTAL REGULATION 42-43 (Resources for the Future Discussion Paper, 1990).

127. For example, James Tobey's study, supra note 51 , appeared in 1990 but was based in large part on 1975 and 1977 data. Kalt's study, supra note 22, published in 1985, was based on 1977 data.

128. See Comprehensive Environmental Response, Compensation, and Liability Act (CERCLA), 42 U.S.C.A. $\$ \$ 9601-9675$ (West 1983 \& Supp. 1992); Resource Conservation and Recovery Act (RCRA), 42 U.S.C. $\$ 6924(u)$ (1988) (corrective action requirements).

129. See U.S. Hazwaste Cleanup Costs Could Hit $\$ 420$ Billion Over 20-30 Years, HaZARDous WaSTE Bus., July 1, 1992, at 3. 
countries affect the costs and competitiveness of their industries. This inquiry faces additional difficulties, however. One is distinguishing the law in action from the law in the books. Two countries may, for example, have exactly the same standards in their statutes or regulations, but the effectiveness of these standards depends almost entirely on how the law is interpreted and administered, the strength and credibility of monitoring and enforcement, and the level of sanctions imposed for violations. ${ }^{130}$

Another complicating factor is that international divergences in regulatory compliance costs may be due not only to variations in the stringency of environmental measures, ${ }^{131}$ but also to differences in the regulatory instruments and legal and administrative systems used to implement those standards. Regulatory approaches that allow sources more flexibility in achieving pollution reductions, or that allocate the burden of reductions in accordance with differences in control costs among sources, reduce the overall costs to industry of achieving any given level of environmental quality. A 1985 Congressional Budget Office study found that the adverse impact of environmental regulation on annual productivity growth in Japan was quite small $(.06 \%)$ compared to that in the U.S. (.28\%). It stated that this difference might well be due to the greater flexibility of the Japanese regulatory system, observing that "the actual standards set by the regulatory process may be less important ... than is the manner in which the regulations are carried out."132 This distinction has important policy implications. Suppose, for example, that the U.S. sought to justify unilateral restrictions on imports on the ground that studies showed its environmental compliance costs were significantly higher than those of other countries. The costly nature of the rigid, command-and-

130. See supra note 62 and accompanying text.

131. In making comparisons among countries, the type of standard analyzed is also important. A common technology-based pollution control standard that, for example, requires a given level of pollution reduction from all sources in an industry category would, other things being equal, impose the same compliance costs on corresponding industries in different countries. However, an environmental quality standard that imposes only such source controls as are necessary to prevent the concentration of a pollutant in the ambient air or water from exceeding a given level would result in different compliance costs for industries in different countries depending on the assimilative capacity of the natural environment, the country's size, the extent and geographical concentration of its industry, and its existing pollution levels.

132. CONGRESSIONAL BUDGET OFFCE, supra note 98, at 84; see also OECD, ENVIRONMENTAL POLICY AND TECHNICAL CHANGE 31 (1985) (manner in which regulations are implemented can aggravate or reduce adverse effects on innovation of regulatory risk and uncertainty); Gregory C. Pratt, Air Toxics Regulation in Four European Countries and the United States, 4 INT'L ENVTL. AFF. 79 (1992) (contrasting goaloriented European approach to regulation with legalistic U.S. approach).

It is also conceivable that otherwise similar industries in different countries have different compliance costs because of differences in managerial skill, know-how, innovation, and entrepreneurship. With the growth of multinational competition and flexibility in plant location, one might expect that this would not be an important factor. If, however, Japanese companies can build high quality cars substantially more cheaply than their U.S. competitors, they may also be able to achieve compliance with environmental requirements more cheaply. Environmental performance may depend importantly on the priority that management gives to the issue, its willingness to take a forward-looking, proactive approach to pollution prevention rather than a short-term, reactive response to existing requirements, and other such factors. 
control system used in the U.S. would undercut this asserted justification for unilateral trade barriers. ${ }^{133}$

Another problem is presented by basic differences in national strategies that may make it difficult to decide whether programs in some nations without counterparts elsewhere should be counted as environmental measures. Consider, for example, high energy taxes in Europe and Japan that discourage fossil fuel combustion, thereby reducing pollution. It would seem that at least part of industry's payments of such taxes should be counted as environmental compliance costs. But how much? The studies summarized above did not take such taxes into account. The result is a potentially misleading picture of the costs of environmental policies in Japan and Western Europe as compared to the U.S., where energy taxes have been minimal or nonexistent.

\section{Industries Exceeding Minimum Standards}

A further difficulty in attempting to correlate differences in the stringency of environmental standards with differences in industry costs and competitiveness is that industry may not take advantage of less stringent standards but may choose, for various reasons, to achieve a higher level of environmental protection than is legally required. This situation is especially likely to arise in the case of OECD multinationals operating in less developed nations. A study of industrial development in Chile ${ }^{134}$ and another study of the development over the past 25 years of the wood pulp industry in developing nations ${ }^{135}$ found that new industrial projects achieved much higher degrees of pollution control than legally required, in many instances comparable to those achieved in developed countries. Similar findings have been reported for the fertilizer industry in Bangladesh ${ }^{136}$ and steel manufacturing in developing countries. ${ }^{137}$

One explanation for this phenomenon offered in the case studies is that the newest, low-cost technology, typically imported from developed countries, often has a high level of built-in pollution control. ${ }^{138}$ For reputational and prudential reasons (including fear of another Bhopal), multinational companies are reportedly improving environmental health and safety standards for all

133. See infra notes $218-225$ and accompanying text.

134. Nancy Birdsall \& David Wheeler, Trade Policy and Industrial Pollution in Latin America: Where are the Pollution Havens?, in WORLD BANK PAPERS, supra note 6, at 159, 167.

135. David Wheeler \& Paul Martin, Prices, Policies, and the International Diffusion of Clean Technology: The Case of Wood Pulp Production, in WORLD BANK PAPERS, supra note 6, at 197, 214.

136. Mainul Huq \& David Wheeler, Pollution Reduction Without Formal Regulations: Evidence From Bangladesh (World Bank Technical Paper) (unpublished manuscript, on file with author).

137. David Wheeler et al., Process Change, Economic Policy and Industrial Pollution: Cross Country Evidence from the Wood Pulp and Steel Industries 11-12 (unpublished paper presented at American Economic Ass'n, Anaheim, CA, January 5-7, 1993).

138. See, e.g., Wheeler \& Martin, supra note 135 , at 214. 
facilities, regardless of location. ${ }^{139}$ Some projects are financed in part by multilateral or bilateral development banks, which could promote high levels of control. ${ }^{140}$ "Green consumerism" and regulatory requirements in the developed countries to which a facility's products are exported may lead to stringent process controls in order, for example, to ensure that paper products do not contain process dioxin residues. ${ }^{141}$ Or, companies may be concerned that there will be an upsurge in domestic environmental concerns that will produce much tougher regulations in the future; it may be cheaper to anticipate this risk by building in pollution prevention measures at the outset rather than retrofitting.

Are these case studies representative? If they are, they would have both a narrow and a broad significance. The narrow point is that in the context of empirical studies of differences among countries, one cannot assume that variations in regulatory standards will be matched by correlative differences in compliance costs. The potentially broader point is that differences in national standards may not affect international competitiveness as significantly as one might expect because new projects in countries with less stringent standards may achieve relatively stringent control levels for reasons unrelated to the governing legal standards. If so, there would be less need to harmonize national standards, at least for new facilities, in order to meet competitiveness concerns, although harmonization would also be less difficult to achieve.

\section{Review of the Empirical Studies}

The empirical literature attempting to correlate differences in national environmental standards and international competitiveness ${ }^{142}$ includes three basic types of studies: productivity studies, trade studies, and locational studies. The following review summarizes the general conclusions that emerge and provides examples of individual studies in order to give the reader a concrete feel for the nature of the data and analyses on which these conclusions are based.

139. Business, Environment Linked by Efficiency, Swiss Industrialist Says, Int'l Env't Daily (BNA), June 18, 1992, available in LEXIS, Nexis Library, BNAIED File; Ann Rappaport \& Margaret Flaherty, Multi-National Corporations and the EPA: Context and Challenges, 14 Int'l Env't Rep. (BNA) 261 (May 8, 1991), available in LEXIS, BNA Library, INTENV File.

140. See, e.g., Western Environmental Protection Law Said Difficult to Transplant to Asia, 11 Int'1 Env't. Rep. (BNA) 291 (May 11, 1988) (reporting that establishment of standards by international lending institutions such as Asian Development Bank helps ensure that Japanese-sponsored development projects have minimal environmental impact).

141. See Nancy Birdsall \& David Wheeler, Trade Policy and Industrial Pollution in Latin America: Where are the Pollution Havens?, in WORLD BANK PAPERS, supra note 6, at 159, 162.

142. For an overview, see Judith M. Dean, Trade and the Environment: A Survey of the Literature, in WORLD BANK PAPERS, supra note 6, at 15. 


\section{Productivity Studies}

Economic productivity measures the value of commodity outputs ${ }^{143}$ in relation to factor inputs. There are many different measures of commodity productivity depending on the choice and definition of the relevant outputs and inputs. ${ }^{144}$ Firms and industries with higher productivity can produce the same output as their competitors at less cost and thereby gain competitive advantage. Regulatory requirements and the threat of liability lead firms to take prevention and control measures that increase the cost of factor inputs and reduce commodity output, lowering productivity as conventionally measured. ${ }^{145}$

Several studies have estimated the effects of environmental regulation on U.S. industrial productivity. ${ }^{146}$ For example, a 1985 Congressional Budget Office report surveyed studies based on 1970's data. Excluding two outlying estimates, the studies indicated that U.S. productivity growth had declined between $.1 \%$ and $.3 \%$ annually as a result of pollution regulation; the decline in productivity growth became smaller at the end of the decade after the first round of investments to meet regulatory requirements enacted in the early 1970 's. ${ }^{147}$

Regulation has since intensified. A recent, sophisticated study by Jorgenson and Wilcoxen examined the impact of air and water pollution control requirements on thirty-five U.S. industries during the 1973-85 period, using a model that incorporated input/output analysis to trace the ripple effects of the compliance costs throughout other sectors. ${ }^{148}$ It found that the aggregate annual growth in GNP would be $.034 \%$ higher in the absence of the increased operating costs imposed by environmental regulation, $.074 \%$ higher in the absence of imposed investment costs, and $.051 \%$ higher in the absence of motor vehicle controls. ${ }^{149}$ The effect on measured output, and hence competitiveness, varied widely by industry. ${ }^{150}$

Another recent study by Barbera and McConnell examined the decline in the growth of total factor productivity during the 1970's in five U.S. industries

143. Repetto, supra note 110 . These measures are generally based on national income accounts that ignore many of the benefits of environmental protection measures. Id. at 38 .

144. CONGRESSIONAL BUDGET OFFICE, supra note 98 , at 62 .

145. Increased environmental quality will increase a society's real economic welfare, but this increase is not measured in conventional national income accounts except to the extent that it lowers production or consumption costs by, for example, increasing agricultural yield or reducing corrosion. As previously noted, see supra text accompanying notes $115-116$, these benefits generally accrue to persons other than the firms subject to regulation and are difficult to trace and measure. As a result they are generally disregarded in studies of the costs of complying with environmental requirements.

146. See CONGRESSIONAL BudGeT OFFCE, supra note 98; Anthony J. Barbera \& Virginia D. McConnell, The Impact of Environmental Regulations on Industry Productivity: Direct and Indirect Effects, 18 J. ENVTL. ECON. \& MGMT. 50 (1990); Jorgenson \& Wilcoxen, supra note 22.

147. See CONGRESSIONAL BUDGET OFFICE, supra note 98 , at 68 .

148. Jorgenson \& Wilcoxen, supra note 22.

149. Id. at $338-39$.

150. Id. at 336. 
as a result of pollution regulation: paper; chemicals; stone, clay and glass; iron and steel; and non-ferrous metals. ${ }^{151}$ Comparing measured productivity for the 1970's to the 1960's, they found a reduction in the rate of productivity growth of between $.12 \%$ and $.43 \%$ annually, or between $10 \%$ and $30 \%$ of the total decline in productivity growth in these industries during the 1970 's. ${ }^{152}$

In the context of international competitiveness, however, we are interested in the impact of environmental requirements on productivity growth in the U.S. relative to other countries. Here the available studies are sparse. The 1985 Congressional Budget Office study found environmental compliance outlays had a significantly less adverse impact on annual productivity growth in Japan $(.06 \%)$ and Canada (.14\%) than in the U.S. (.28\%). ${ }^{153}$ An OECD study based on 1970's data found that real output in the U.S. and selected European nations was then $.5 \%$ to $2.2 \%$ lower as a result of environmental regulation. In Japan, output was only $.01 \%$ lower. ${ }^{154}$ These studies did not attempt to correlate such differences with differences in regulatory stringency. Nevertheless, environmental standards in Japan and the U.S. are not sufficiently dissimilar to explain such disparities, which therefore must be due to other factors such as differences in legal and administrative systems. ${ }^{155}$

Overall U.S. productivity growth during the past two decades was significantly lower than it had been during the previous two decades. Annual productivity growth was $2.9 \%$ from 1947-55, 2.5\% from 1955-68, 1.5\% from $1968-73,0.4 \%$ from $1973-80$, and $1.1 \%$ from $1980-86 .{ }^{156}$ Numerous factors have been cited as contributing to this decline in addition to the costs of environmental regulatory programs, including the energy price shocks of the 1970 's and 1980 's; ${ }^{157}$ insufficient $R \& D$ expenditures; ${ }^{158}$ diminishing $R \& D$

151. Barbera \& McConnell, supra note 146.

152. Id. at 62 .

153. See CONGREssional BudGet OfFICE, supra note 98 , at 69 . The figures in the text are derived from Table 18 presenting data on productivity growth both with and without pollution control equipment outlays.

154. See id. at 70.

155. A recent study by Stephen Meyer correlated various measures of differences in the stringency of environmental programs in the different states of the U.S. with various measures of economic performance, including growth in GDP and labor productivity. STEPHEN M. MEYER, ENVIRONMENTALISM AND ECONOMIC PROSPERITY: TESTING THE ENVIRONMENTAL IMPACT HYPOTHESIS (Massachusetts Institute of Technology, Project on Environmental Politics and Policy, Oct. 5, 1992). He found that states with stronger environmental programs had better economic performance. This study, however, cannot support the conclusion that stringent national environmental standards do not adversely affect productivity. Because of federal legislation in the U.S., differences in environmental regulation of industry among U.S. states is far less than differences in regulation among nations. Moreover, Meyer did not test the hypothesis that economically stronger states would have had even higher levels of economic performance had they not chosen higher environmental standards.

156. Stanley Fischer, Symposium on the Slowdown in Productivity Growth, 2 J. EcoN. PERSP., Fall 1988, at 3, 5 tbl. 2 .

157. See, e.g., Zvi Griliches, Productivity Puzzles and R\&D: Another Nonexplanation, 2 J. ECoN. PERSP., Fall 1988, at 9, 19 (arguing that "prime suspect" for slow productivity growth over the last decade "remains the rise in energy prices and its macro consequences."); Dale W. Jorgenson, Productivity and Postwar U.S. Economic Growth, 2 J. ECON. PERSP., Fall 1988, at 23, 34 (noting that "increases in the prices of capital, labor, and energy inputs diminish the rate of productivity growth" and that "most striking 
returns; ${ }^{159}$ the changing composition of the work force; ${ }^{160}$ insufficient investment (or savings), resulting in less than optimal new capital; ${ }^{161}$ and poor managerial performance. ${ }^{162}$ The studies reviewed above indicate that environmental regulatory costs, defined in terms of compliance outlays, accounted on average for around $.2 \%$ of the decline in annual productivity growth during the past two decades. This represents a significant but not overwhelming portion of the total decline. The adverse effect of environmental regulation on productivity is greater for more intensively regulated industries. The limited data comparing countries show that the adverse effects of compliance outlays on productivity in the U.S. is somewhat greater than in Western Europe and much greater than in Japan. More stringent U.S. environmental standards might account for the difference with respect to at least some Western European countries, but it cannot explain the difference with respect to Germany and Japan, which have regulations of similar stringency.

\section{Trade Studies}

If environmental regulation in country $A$ imposes significantly higher costs on $A$ 's industries than the environmental compliance costs of its trading partners' industries, $A$ would export relatively more commodities that had low environmental compliance costs associated with their production, and would import relatively more commodities that have higher pollution control costs associated with their production.

Some studies have used this logic in examining imports and exports for the U.S. ${ }^{163}$ A thorough study following this approach which found substantial trade effects from environmental policies was conducted by Kalt. ${ }^{164}$ It was based on 1977 compliance cost data for different U.S. industries. Using multisectoral input/output analysis, it found a significant negative correlation between export performance and compliance costs. ${ }^{165}$

change" in these relative prices "since 1973 is the substantial increase in the price of energy.").

158. See, e.g., Edward N. Wolff, The Magnitude and Causes of the Recent Productivity Slowdown in the United States: A Survey of Recent Studies, in PRODUCTIVITY GROWTH AND U.S. COMPETrTIVENESS 29, 51 (William J. Baumol \& Kenneth McLennan eds., 1985) (citing one study that shows reduced R\&D investment resulted in $10 \%$ productivity slowdown).

159. Edward F. DENISON, TRENDS in AMERICAN ECONOMIC Growth 1929-1982 40-44 (1985). Denison assigns a quite minor role to environmental regulation as a factor in productivity slowdown. Id. at 44 .

160. See, e.g., Wolff, supra note 158 , at 51 .

161. See, e.g., id. at 49.

162. See, e.g., DENISON, supra note 159, at 44-47.

163. See PASURKA \& NESTOR, supra note 51, at 4; Kalt, supra note 22, at 222-23; Low \& Yeats, supra note 51 , at 90-91; Tobey, supra note 51.

164. Kalt, supra note 22.

165. Id. at 246 (stating that "an increase in the stringency and cost of environmental regulations has a negative effect on trade performance."). 
Kalt also compared imports and exports for different sectors of U.S. industry, using a Heckscher-Ohlin analysis. This analysis examines the statistical relation between factor abundance and exports and imports. If a nation is relatively abundant in an input factor compared to its trading partners, it should export relatively more of the commodities for which that factor is an important input. Conversely, it should import more commodities with respect to which it is relatively poor in input factors. Nations with a high assimilative capacity have relatively abundant environmental resources for disposal of industrial residuals. They will accordingly enjoy a comparative advantage, resulting from less stringent pollution control requirements. ${ }^{166}$ An examination of the composition of the pollution intensity of exports and imports thus indicates the comparative advantage that a nation enjoys in assimilative capacity. Kalt's analysis found that in 1977 , U.S. exports were significantly less pollution-intensive than imports. ${ }^{167}$ This was not the case in $1967 .^{168}$ Kalt attributes the difference to the adoption of relatively stringent environmental requirements in the U.S., which effectively reduced its assimilative capacity (by restricting emissions), and thereby created a regulatory-based comparative U.S. disadvantage reflected in the composition of exports and imports. ${ }^{169}$

Other studies have examined trade performance across many countries. Low and Yeats analyzed trade patterns in exports of "dirty" industries in different countries. ${ }^{170}$ They defined "dirty" industries as those with the highest pollution control costs in the U.S., ${ }^{171}$ reasoning that such industries are inherently highly polluting. They found that during the $1965-88$ period the relative proportion of "dirty" product exports in various countries' total exports fell for the developed countries and increased significantly in Eastern Europe, Latin America, and West Asia. The most significant export decline was from North America and the most significant import increase was in Southeast Asia. ${ }^{172}$ Using a Heckscher-Ohlin analysis of revealed comparative advantage based on export/import patterns for different industry sectors, they also found that the developing countries enjoyed a rapidly increasing comparative advantage in pollution-intensive products during this period because their exports of dirty industry products grew more rapidly than exports generally. ${ }^{173}$ Since developing countries generally have far less stringent environmental standards, this finding suggests that differences in environmental

166. This analysis assumes that governments will appropriately set environmental requirements based on relative assimilative capacity.

167. Kalt, supra note 22 , at 249.

168. Id.

169. Id. at 258.

170. Low \& Yeats, supra note 51, at 90.

171. Id. at 91 .

172. Id. at 93 .

173. Id. at 102 . 
standards had a significant effect. The authors note, however, that pollution control expenditures are a relatively small percentage of production costs. They offer potential alternative explanations for the observed trade shift: the pull of lower-cost labor or natural resources in the developing countries, or a compositional effect reflecting the relatively greater importance of pollutionintensive processes in national output during a nation's stage of heavy industrialization. ${ }^{174}$ This study, like the others summarized here, did not specifically examine other variables, such as wage rates or taxes, that might affect locational decisions.

A 1990 application of Heckscher-Ohlin analysis by Tobey ${ }^{175}$ examined trade patterns for different countries in products made by industries facing high pollution control costs: mining, primary non-ferrous metals, paper and pulp, primary iron and steel, and chemicals. In the U.S. in 1977, pollution abatement outlays for these industries ranged from $1.92 \%$ to $2.89 \%$ of total production costs. ${ }^{176}$ Tobey also used a qualitative 1976 ranking of the stringency of pollution control requirements in different countries, and examined whether this ranking could account for variations in the 1975 trade flows among these nations. He found for these industries no statistically significant correlation between regulatory intensity and export/import performance. ${ }^{177}$

A 1992 EPA study estimated the impact of the additional cost of requirements imposed by the 1990 Clean Air Act Amendments on the production costs and trade performance of three industries. ${ }^{178}$ It projected that by 2010 chemical manufacturing imports would rise between $.08 \%$ and $4.11 \%$, and exports would decrease between $.14 \%$ and $.92 \%{ }^{179}$ For automobiles, imports were projected to rise $.02 \%-.23 \%$, and exports to fall $.02 \%-.41 \%{ }^{180}$ In the case of iron and steel manufacturing, imports were estimated to increase $.12 \%-.64 \%$, and exports to decrease $.17 \%-.98 \%{ }^{181}$ These effects are discernible but not large. The study, however, is limited to the effects of incremental changes in a single regulatory statute.

Thus, the various trade studies, which are based mainly on data from the 1960's and 1970's, indicate that environmental compliance outlays have some impact on trade performance, but that the impact is not significant for most industries. The effect is more substantial for the intensively regulated industries

174. Id. at 103 .

175. Tobey utilized an extension of the Heckscher-Ohlin analysis, the Heckscher-Ohlin-Vane (HOV) model of international trade. The HOV equations are a multi-factor, multi-commodity extension of the Heckscher-Ohlin model. Tobey, supra note 51, at 194.

176. Id. at 193.

177. Id. at 197. Using an omitted variable analysis, Tobey also found that possible differences in environmental regulation between countries could not explain differences in trade flows for the industries in question during the years 1970-1984. Id. at 201.

178. PASURKA \& NESTOR, supra note 51.

179. Id. at $41-42$.

180. Id. at 43 .

181. Id. at $39-40$. 
and may explain the increase in developing country exports in such industries, although there are alternative explanations for developing country performance. ${ }^{182}$

\section{Locational Studies}

Locational studies seek to determine whether trends in the geographical distribution of process facilities among different jurisdictions correlate with differences in the jurisdictions' environmental regulations. If environmental process standards significantly affect competitive advantage, investment in production facilities should move from nations with stringent standards to those with lower standards. This shift may occur through new plant locations, shutdown of existing plants, or relocation of existing facilities from one nation to another. ${ }^{183}$

A number of studies of industrial location within the U.S. have found that differences in environmental standards are a minor factor in decisions regarding the siting of new facilities. ${ }^{184}$ More determinative are traditional factors such as raw material, labor, and other input supplies, access to markets, transportation, general business climate, quality of life, and taxes. ${ }^{185}$ Because of federal legislation and other factors, however, the differences in environmental requirements among the various states in the U.S. are not as great as the differences in requirements among nations. Still, international studies have not identified any significant, broad-scale locational effects that can be attributed to variations in environmental standards, although there is evidence of such effects in the case of the most intensively-regulated industries. ${ }^{186}$ These results may again reflect that environmental compliance outlays are a small percentage of overall production costs for most industries.

For example, in a recent study, Lucas, Wheeler, and Hettige ${ }^{187}$ examined changes in the relative output of various industrial sectors in different countries during the years 1960-88. They then imputed different degrees of toxic pollution intensity to these sectors, based on toxic release data for U.S. industry. They did not consider possible inter-country differences in process technologies, pollution control levels, or productive efficiencies within the same industry. They found that, beginning in the 1970's, there was a

182. See Low \& Yeats, supra note 51, at 103.

183. See infra notes 193-197 and accompanying text.

184. See id.

185. Christopher J. Duerksen, ENvirommental Regulation of Industrial Plant Siting: How

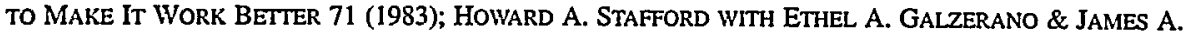

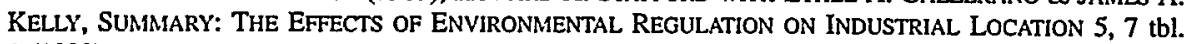
1 (1983).

186. See infra notes 187-191, 198-203 and accompanying text

187. Robert E.B. Lucas et al., Economic Development, Environmental Regulation and The Intemational Migration of Toxic Industrial Pollution: 1960-1988, in WORLD BANK PAPERS, supra note 6, at 67. 
significant growth in the relative toxic intensity of sectoral output in the less developed countries, with the greatest growth in the poorest countries. ${ }^{188}$ They conclude that this pattern is consistent with the hypothesis that "dirty" industry migrated to nations with less stringent environmental requirements, but they also note that the pattern might be explained by a compositional effect. ${ }^{189}$ As nations develop, they go through an industrialization stage where relatively high-polluting activities represent a relatively large share of national output. ${ }^{190}$ The analysis by Low and Yeats summarized above, of changes in trade flows as a proxy for changes in the pattern of industrial location, reached similar conclusions. ${ }^{191}$

Birdsall and Wheeler examined changes in the pollution intensity ${ }^{192}$ of output in developing countries from 1960 through 1990 which resulted from shifts in the sectoral composition of output. ${ }^{193}$ They did so in order to test the hypothesis that international trade in product and investment would lead to the migration of industry to less developed countries, which tend to have less stringent environmental requirements. This hypothesis predicts a faster growth in industrial pollution intensity in economies that are relatively open to trade (those with low trade barriers and few restrictions on capital flows) as opposed to relatively closed economies. Contrary to their hypothesis, they found that the relatively closed economies were more pollution-intensive. ${ }^{194}$ This finding might, however, reflect that governments seeking to close their economies were more likely to have invested in heavy, highly-polluting industries or adopted lower environmental standards (a variable not examined in the study).

Leonard examined international locational issues for two heavily regulated industry sectors: chemicals (including petrochemicals) and mineral processing. ${ }^{195}$ One indicator of "industrial flight" would be increased direct investment by heavily regulated U.S. industries in facilities abroad. Leonard found a small increase in such investment by the chemical and mineral processing industries from 1970-80, and also found a small increase in the share of such investment by developing countries. ${ }^{196}$ However, the increase in heavily regulated industries' investment in developing countries was no greater than that of U.S. industry as a whole. ${ }^{197}$

188. Id. at 76 .

189. Id. at $69,72,80$.

190. Id. at 72 .

191. Low \& Yeats, supra note 51, at 102-03.

192. Their measurement of pollution intensity was based on U.N. data for toxic releases from different industries.

193. Nancy Birdsall \& David Wheeler, Trade Policy and Industrial Pollution in Latin America: Where Are the Pollution Havens?, in WORLD BANK PAPERS, supra note 6, at 159.

194. Id. at 167.

195. LEONARD, supra note 8.

196. Id. at $94,96$.

197. Id. at 96 . 
When the foreign investment analysis was focused on capital expenditures, however, Leonard found a significant increase in new plant and equipment investment by U.S. chemical and mineral-processing firms in Brazil, Mexico, Spain, and Ireland. ${ }^{198} \mathrm{He}$ also examined trends from 1971-81 in U.S. imports of chemical and mineral-processing products, including a separate analysis of imports from U.S. overseas affiliates. Leonard found a decline in imports of chemical products but a significant increase in imports of processed minerals, indicating displacement of U.S. processing capacity overseas. ${ }^{199}$ On the basis of this and other evidence, Leonard concludes that environmental regulations have not, in general, caused "industrial flight" from the U.S. ${ }^{200} \mathrm{He}$ does find, however, that there has been some displacement effect for some heavily regulated industries whose production processes are highly polluting, creating serious occupational as well as environmental risks, and whose declining or stagnant market position makes it difficult for them to finance necessary controls or process renovations. ${ }^{201}$

Another survey found that highly toxic asbestos tile and benzidine dye manufacturing facilities had relocated to Mexico and Romania, respectively, in order to escape stringent environmental regulation. ${ }^{202}$ The General Accounting Office found that environmental requirements, in addition to labor costs, were important factors in the relocation of some wood furniture manufacturers from Southern California to Mexico. ${ }^{203}$

Taken together, the locational studies indicate that environmental requirements have not affected the location of most industries, but that there has been a discernible and in some cases significant shift in the location of a few intensively-regulated industries from developed to developing countries. These findings are consistent with the results of the trade studies. It is plausible that this locational shift is attributable in part to differences in environmental standards, although in some instances it may also be attributable to a compositional effect.

\section{4. "The Race to the Top"}

The analysis thus far has proceeded on the assumption that environmental regulation and liability rules impose costs on industry that impair its

198. Id. at $96-100$.

199. Id. at 105.

200. Id. at 115 .

201. Id. at 111-13.

202. Frances Cairncross, Cleaning Up (A Survey of Industry and the Environment), ECONOMIST, Sept. 8,1990 , at 24.

203. United States General accounting OfFice, U.S.-MeXico Trade: SOME U.S. Wood FINISHING FIRMS RELOCATED FROM LOS ANGELES AREA TO MEXICO 4-5 (1991). However, only 1-3\% of all Los Angeles firms relocated, affecting 2-10\% of wood furniture manufacturing employees in the Los Angeles area. On the other hand, significantly more firms had plans to relocate. Id. at 3 . 
international competitiveness. However, a growing body of thought challenges this conventional assumption, arguing that nations adopting more stringent environmental requirements will actually enhance the international competitiveness of their industries. The argument is also made that industries which voluntarily choose to pursue higher levels of environmental quality will benefit economically. ${ }^{204}$

This argument has two strands. The first, articulated by Michael Porter, is that there is likely to be a worldwide movement towards more stringent environmental requirements, including measures to deal with emerging problems such as climate change. ${ }^{205}$ Those countries that adopt relatively more stringent environmental requirements now will create, in effect, a demand for development of less polluting processes and products by their industries. ${ }^{206}$ As a result, their industries will enjoy a head start in developing the requisite technologies. When other nations eventually "follow the leader" and adopt similarly stringent requirements, the leader country's industry will enjoy a dominant position in the growing international market for "green" technology. ${ }^{207}$ This is the "race to the top."

A second strand in the argument is that new technologies that meet high standards of environmental performance tend to be highly resource efficient, resulting in economic benefits in the form of lower production costs as well as environmental benefits. ${ }^{208}$ Accordingly, stringent environmental requirements stimulate innovation and promote investment in advanced technologies that will strengthen industrial competitiveness.

It would be attractive to suppose that economic and environmental goals are as neatly congruent as these arguments suggest. There are, however, grounds for skepticism. It is true that the international market for environmental products and services is growing rapidly; nevertheless, it amounts to substantially less than $1 \%$ of total world trade. ${ }^{209}$ The potential

204. See, e.g., Dirtier than the Rest, supra note 46 , at 7,8 .

205. Id. at 8 . For general discussion of the relation between government policies and international competitiveness, see Porter, supra note 9, at 617-82.

206. See OECD, THE OECD ENVIRONMENT INDUSTRY: STTUATION, PROSPECTS, AND GovernMENT POLICIES 19 (1992) [hereinafter OECD, ENVIRONMENT INDUSTRY] (noting relative advantage of German companies in water pollution control technology, Japanese firms in air pollution control technology, and U.S. firms in hazardous waste management, reflecting relative stringency of domestic regulation of these problems).

207. Id; see also PORTER, supra note 9, at 45-47 (discussing how government regulation can lead to shifts in competitive advantage). This analysis is potentially applicable to product as well as process regulatory standards. In the case of product regulation, if the country adopting stringent standards has a large domestic market for the product, manufacturers in other countries will have to meet those standards in order to gain access to its market. Within the European Community, Germany has often adopted more stringent product and process standards and succeeded in provoking EC legislation to adopt similar standards for the Community as a whole. In the international context, however, there is far less assurance that one nation's unilateral adoption of stringent standards will be widely imitated.

208. See OECD, ENVIRONMENTAL Policy AND TEChNICAl ChaNGE 34 (1985); Pratt, supra note 132, at 98 .

209. The worldwide market for pollution control has been estimated at $\$ 200$ billion as of 1990 . OECD, ENVIRONMENT INDUSTRY, supra note 206, at 15. World Gross Domestic Product was $\$ 16.4$ trillion in 1991 . 
competitive benefits in the international market for "green" technologies that may result from a nation's adoption of more stringent standards must be weighed against the competitive detriments imposed by the costs of more stringent standards. There appear to have been no empirical studies of this issue. Moreover, any such international competitive benefits will depend in large part on the nature of the domestic requirements in question. Requirements for merely wider adoption of already available technology will create fewer competitive benefits than those that provide flexibility and rewards for innovation.

There are also grounds for skepticism that more stringent standards will generally reduce net production costs by stimulating adoption of more resource-efficient technologies. If such technologies significantly reduce production costs, why have they not already been developed and used by firms for economic reasons alone? Here one must invoke Simon-March theories of industrial organization, which hold that business firms do not constantly strive to pursue every opportunity to maximize profit, but instead "satisfice" and often become mired in institutional routines that inhibit the development of promising and profitable new ways of doing business. ${ }^{210}$ Environmental regulation could potentially provide the external stimulus that provokes management to discover opportunities for reducing costs that it had hitherto neglected.

While one reads abundant anecdotal evidence that environmental regulations have led companies to develop new production processes and techniques that reduce compliance costs through enhanced resource efficiency, ${ }^{211}$ systematic studies are lacking. An exception to this generalization is a study by Barbera and McConnell of five heavily regulated U.S. industries. ${ }^{212}$ They distinguished capital investment to reduce or control pollution (which they term the direct effect of environmental regulation) from associated changes in conventional capital and changes in operating costs (indirect effect). In two of the industries examined, the indirect effects reduced

PREDICASTS, INC., WORLD CASTS PRODUCT, Issue 106, May 13, 1992, at B-44. OECD estimated that world trade in pollution control goods and services is $\$ 26$ billion. OECD, ENVIRONMENT INDUSTRY, supra note 206 , at 21 . Total world trade was $\$ 3.8$ trillion in 1989. GENERAL AGREEMENT ON TARIFFS AND TRADE, 1 INTERnATIONAL TRADE '89-'90, at 1 (1990).

For discussion of "green trade," see Clive Capps, Green Trade Boom, BENN PUBLICATIONS LTD., May 5, 1992, at 51; Helen E. Jung, U.S. Firms Lag in Eco-Marketing, SEATTLE TIMES, Sept. 18, 1992, at C4; Varied Interests Push for U.S. Policy to Emphasize "Green" Technologies, AIR WATER POLLUTION REP., July 13, 1992.

210. See Richard M. Cyert \& James G. March, A Behavioral Theory of THE Firm 9-10 (1963); Herbert A. Simon, Theories of Decision-Making in Economics and Behavioral Science, 49 AM. ECON. REV. 253, 277 (1959).

211. See, e.g., Richard A. LiRoff, Reforming Air Pollution: THE TOIL AND Trouble of E.P.A.'s BUBbLE 67, 68 (1986) (citing 3M's development of solventless system to reduce ozone emissions in response to environmental regulation); Ken Geiser, The Greening of Industry; Pollution Control in a Sustainable Industry, TECH. REv., Aug. 1991, at 64; Chris Isidore, More Businesses Find Clean Can Mean Higher Profits, Too, N.Y. TIMES, Jan. 5, 1993, at A7.

212. See Barbera \& McConnell, supra note 146 , at $62-63$. 
costs, but not enough to offset the costs of the direct effect. ${ }^{213}$ In the other three industries, the indirect effects resulted in additional production costs over and above the costs of the capital equipment required to meet environmental standards. ${ }^{214}$

This limited evidence suggests that competitiveness benefits alone are in most instances unlikely to justify the adoption of more stringent environmental measures. However, where more stringent measures are justified for other reasons-such as improved environmental quality, reduced dependence on energy imports, or reduced traffic congestion-competitiveness benefits become highly relevant in the selection of the policy instruments to achieve these goals. Instruments such as market-based incentives or environmental contracting ${ }^{215}$ that stimulate innovation and resource efficiency will provide competitiveness benefits by reducing the costs of achieving these goals and encouraging the development of "green" technologies with export potential. Adherence to centrally planned command strategies of regulation will undermine competitiveness. If societies around the world continue to seek higher levels of environmental quality, the competitive benefits of using innovation-promoting instruments to achieve these levels of environmental quality will increase. Not only will the costs of complying with environmental requirements be reduced, but opportunities for export sales will be enhanced. In this respect, the race to the top notion has an important kernel of truth.

\section{Long-run Impact on Innovation and Investment}

Studies available to date may not have fully captured the adverse effects on the productivity of the U.S. legal and regulatory system. Most recent studies of international competitiveness are based on data from the 1970's and the early 1980's, which represented the first phase of pollution control. The developed countries pushed to require installation of available "end-of-pipe" technologies, such as flue gas desulphurization scrubbers, secondary treatment, and automobile exhaust control systems. In this stage, the comparative disadvantage of the U.S. regulatory system was less pronounced, its extent too small to show through the statistical "noise" in the necessarily somewhat crude empirical studies based on data from this period. Since the mid-1980's, environmental regulation has entered a more ambitious stage, especially in the U.S., Japan, Germany, and a few other European Community nations. ${ }^{216}$ There has been an effort to limit further discharges of widespread "conventional" pollutants, to impose much tighter controls on toxic pollutants,

213. Id. at 60 .

214. Id.

215. These instruments are explained and analyzed infra Section IV(B)(2).

216. See Howard Fine \& Jim Gardner, OC Environmental Firms Go Global: Having Cut Teeth in LA Basin, It's on to Mexico, Poland, etc., 15 ORANGE COUNTY Bus. J. 50, Dec. 14, 1992, at 1. 
to regulate closely the handling and disposal of toxic waste, and to clean up toxic wastes that have been improperly disposed. ${ }^{217}$

The dysfunctions of the relatively centralized, legalistic regulatory system in the U.S. have become more pronounced in this ambitious second stage of regulation, which moves requirements further up industry's cost curves. Compliance outlays under the U.S. regulatory system have increased rapidly and are projected to continue to grow at an accelerating pace. ${ }^{218}$ Pollution control outlays alone exceed $\$ 120$ billion annually and are expected to rise to $\$ 185$ billion by the end of the decade. ${ }^{219}$ The indirect costs of regulation in the U.S. may add a further $50 \%$ to such figures. ${ }^{220}$ Perhaps even more important are the indirect effects of the regulatory constraints, delays, and uncertainties, and the large and often unpredictable liability awards that distinguish the U.S. system. ${ }^{22 !}$ The sweeping, costly U.S. system of liability for cleanup of hazardous wastes is unique. The threat of uncertain and potentially enormous liability awards in the U.S. has made insurers unwilling to provide any coverage at all for such liabilities. ${ }^{222}$ In other developed nations, environmental regulatory systems are more informal, flexible, and cooperative, ${ }^{223}$ environmental liabilities are far less significant, ${ }^{224}$ and litigation is rare. There is nothing comparable in Japan, Germany, or France to the deluge of court litigation and legal regulatory controversy reported every week in dozens of U.S. legal publications and services such as the BNA Environment Reporter, Inside Superfund, Toxics Law Reporter, Environmental Policy Alert, and the Federal Register. Indeed, there is a BNA Daily Environment Reporter which reports new developments in U.S. regulation and litigation every business day. The sheer output of regulatory legalism in the U.S., with all of its attendant transaction costs, delay, and uncertainty, is overwhelming.

217. See EPA to Propose National Standard For Toxic Pollutants Under CWA, 13 HAZARDous WASTE NEws 2, Jan. 14, 1991; Firms in Japan Go Green-A Little, Bus. ASIA, July 16, 1990; 1991 Offers Change To Set Global Environmental Agenda, Int'1 Env't. Daily (BNA), Jan. 16, 1991, available in LEXIS, Nexis Library, BNAIED File.

218. See Cost of a Clean Environment, supra note 99, at 2-1.

219. See id.

220. See Hahn \& Hopkins, supra note 120 , at 74.

221. See supra notes 101-107.

222. See Kenneth S. Abraham, Environmental Liability and the Limits of Insurance, 88 COLUM. L. REV. 942, 959 (1988).

223. See sources cited infra note 252; Pratt, supra note 132, at 93.

224. The European Community has yet to adopt a directive on civil liability proposed four years ago. See European Commission, Proposal for a Council Directive on Civil Liability for Damage Caused by Waste, 1989 O.J. (C 251). An amended, scaled-back version was proposed in 1991. European Commission, Amended Proposal for a Council Directive on Civil Liability for Damage Caused by Waste, 1991 O.J. (C 192). Unlike CERCLA, the proposed directive would not impose liability for wastes discharged before its enactment. See id. art. 13. For discussion of the potential competitiveness implications of the U.S. liability regime, see George C. Freeman \& Kyle S. McSlarrow, Competitive Reality: The Proposed European Community Directive on Civil Liability for Waste-a Comparison with the U.S. Superfund Liability Regime, in RETHINKING SUPERFUND: IT COSTS TOO MUCH, IT'S UNFAIR, IT MUST BE FIXED 79 (National Legal Center for the Public Interest, 1991) [hereinafter RETHINKING SUPERFUND.]. 
These differences in fundamental legal regulatory approaches, when coupled with the overall increasing stringency of environmental requirements, is discouraging investment and innovation in the U.S. relative to other countries, such as Japan, where regulatory and administrative systems produce more cost-effective policies. The magnitude of this penalty cannot be presently determined, but it justifies searching reexamination of the existing regulatory and legal system in the U.S. ${ }^{225}$

\section{EVALUATION}

\section{A. The Competitiveness Impacts of National Differences in Environmental Regulation and Liability Rules}

The empirical studies on productivity, trade, and industrial location are broadly consistent with one another. They show that national differences in environmental regulation have had an important impact at the margin in the case of a relatively few "dirty" industries. ${ }^{226}$ There is also evidence of a more general shift in the location of heavy industrial and chemical facilities and trade advantage in those sectors to developing countries. ${ }^{227}$ Environmental regulation has adversely affected U.S. productivity, and the negative effect on the U.S. is greater than in some other OECD countries, particularly Japan. Still, the studies do not show that environmental requirements are a dominant factor in overall international competitiveness. These studies, however, suffer from two striking limitations. ${ }^{23}$ The first is the failure to include important elements of costs, including the investments and innovations forgone as a result of regulatory restrictions and procedures and the risk-bearing and other costs associated with liability rules. ${ }^{229}$ The second limitation is that almost all of the studies are based on data from the "first phase" of environmental regulation, and thus do not deal with the potential effects of the more ambitious second phase of requirements in which the U.S. and its principal international competitors are now engaged. The indirect costs of U.S.-style regulation and liability rules are probably substantially greater in the second phase of environmental requirements than

225. For an example of such reexamination, see AMERICAN LAW INSTITUTE, REPORTERS STUDY ON ENTERPRISE LIABILITY FOR PERSONAL INJURY (1991).

226. See supra Section III(C).

227. $I d$.

228. See supra Section III(A).

229. Even if invisible opportunity costs are not captured in studies of environmental regulatory costs, they presumably affect comparative national productivity growth and trade performance as well as industry location and would thus be reflected in comparative studies of these indices of competitiveness. As explained in the text which follows, however, these costs have become significant only in the past decade, and could therefore not have been captured by the available studies, almost all of which are based on earlier data. 
the first. ${ }^{230}$ Accordingly, the studies understate the adverse effects of current U.S. environmental law and regulation on competitiveness.

Many people in industry, environmental groups, and Congress argue that differences in national environmental requirements do have a significant impact on competitiveness, and that U.S. industry is suffering as a result of disparities between relatively stringent U.S. regulatory standards and those of many of U.S. trading partners. ${ }^{231}$ In politics, appearance and belief become reality. The burden of proof in the arena of public debate rests on those who would challenge the prevailing belief. Given their limitations, the empirical studies cannot be expected to dispel the widespread belief in U.S. competitive disadvantage.

In principle, competitiveness per se should not be the central concern. Rather, the concern should be the overall performance of the economy, including the environmental benefits as well as the economic costs generated by government regulatory programs and liability rules. Because they are often misdirected and are excessively costly in relation to the environmental benefits that they provide, ${ }^{232}$ U.S. environmental policies and regulatory instruments may unjustifiably retard U.S productivity and growth, quite apart from their effects on international competitiveness. Nevertheless, when plant closings and relocations can be attributed to weakened U.S. competitiveness, the issue focuses public and political attention in a way that charts and numbers illustrating lagging U.S. productivity or regulatory inefficiency do not. ${ }^{233}$

This attention could provide political support for two steps that should be taken in any event. The first is to reexamine and redirect U.S. environmental priorities and adopt better means for achieving them. The second step is to mount additional efforts for international harmonization of environmental laws and to improve the environmental performance of other nations, particularly some of the developing nations, Eastern Europe, and the former Soviet Union. The case for multilateral action is especially compelling in the case of environmental externalities, such as stratospheric ozone depletion and potential climate change, which directly affect the welfare of the U.S. ${ }^{234}$ The political challenge is to channel public concern about competitiveness to improve U.S.

230. See supra notes $218-225$ and accompanying text.

231. See sources cited supra notes 27-33, 37-42.

232. See Stephen Breyer, Analyzing Regulatory Failure: Mismatches, Less Restrictive Alternatives, and Reform, 92 HARV. L. REV. 547, 553-59 (1979); Richard B. Stewart, Regulation, Innovation, and Administrative Law: A Conceptual Framework, 69 CAL. L. REv. 1256, 1263-76 (1981); Ecology and Economy is Focus on Capital Hill; Hearings by Joint Economic Committee, 240 CHEMICAL MARKETING REP. 13, Sept. 23, 1991, at 3; G.S. Khalsa, Former EPA Chief Advocates more Public Involvement on Environment, UPI, Oct. 16, 1986, available in LEXIS, Nexis Library, UPI File.

233. See, e.g., Ansley, supra note 28, at 388-403, 421-25, 436-50; De Fazio, supra note 30, at 7, 8 (article by Oregon Member of Congress citing relocation of Oregon plant to Mexico with loss of 400 jobs).

234. See generally COMMITTEE ON SCIENCE, ENGINEERING, AND PUBlic POLICY, NATIONAL ACADEMY OF SCIENCES, POLICY IMPLICATIONS OF GREENHOUSE WARMING 64-66 (1991) (urging international activities and agreements to slow global warming). 
environmental regulatory policy and promote multilateral approaches to environmental problems, rather than encouraging unilateral U.S. trade restrictions that would likely reduce economic welfare and U.S. competitiveness in the long run.

\section{B. Reexamining U.S. Environmental Priorities and the Means for Achieving Them}

The EPA Science Advisory Board has confirmed independent analysts' findings that current U.S. environmental regulatory programs expend large amounts of societal resources to deal with relatively small risks, while more significant risks receive inadequate attention. ${ }^{235}$ Examples of the former include the large amounts spent on elaborate cleanups of toxic waste sites, ${ }^{236}$ the imposition of costly, uniform, technology-based water pollution controls without regard to the environmental benefits obtained, ${ }^{237}$ and the failure to take into account differences in the toxicity of regulated wastes. ${ }^{238}$ Examples of relative neglect include radon ${ }^{239}$ and water pollution generated by runoff from agricultural and forestry activities, commercial and residential areas, and other diffuse "non-point" sources, as contrasted with "point source" discharges from industrial or municipal waste treatment outfalls. ${ }^{240}$

Much of this mismatch between expenditures and the seriousness of environmental problems is explained by differences between perceptions of risk and actual risk. For example, toxic waste dumps generate far more attention and concern than radon, although the latter presents more serious health risks. ${ }^{241}$ The existing mis-ordering of environmental priorities also stems in

235. SCIENCE ADVISORY BOARD, ENVIRONMENTAL PROTECTION AGENCY, REDUCING RISK: SETTING PRIORITIES AND STRATEGIES FOR ENVIRONMENTAL PROTECTION 7-8, 12 (1990); see also UNITED STATES General ACCOUnTing OfFice, Environmental Protection Issues 8-9 (1992); Keith Schneider, New View Calls Environmental Policy Misguided, N.Y. TIMES, Mar. 21, 1993, at A1. 67,68

236. See John C. Butler III, Superfund: Super Costs, in RETHINKING SUPERFUND, supra note 224, at

237. See A. Myrick Freeman, Water Pollution Policy, in Public POLICIES, supra note 102, at 97, 140 44 (costs of technology-based water pollution control requirements probably exceed benefits).

238. Roger C. Duver, Hazardous Wastes, in PUBliC POLICIES, supra note 102, at 151, 181.

239. See Christopher J. Daggett et al., Advancing Environmental Protection Through Risk Assessment, 14 ColUM. J. ENVTL. L. 315, 323 (1989).

240. See James Lis \& Kenneth Chilton, Clean Water-Murky Policy 1-2 (Washington Univ. Center for the Study of American Business ed., 1992); A. Myrick Freeman, Water Pollution Policy, in PUBLIC POLICIES, supra note 102, at 97, 140-44.

241. See SCIENCE ADVISORY BOARD, supra note 235, at 12 (risks considered most serious by public are different from those considered most serious by technical professionals); Daggett et al., supra note 239 , at 323. Considerable governmental leadership will be required to overcome this mismatch between perceptions and realities. One institutional step that could help educate the public about relative environmental risks and promote the redirection of priorities would be to create a Task Force on Environmental Priorities, chaired by the Vice President, which would be charged with developing a national plan for environmental policies and priorities over the next decade. The Task Force would consult with Congress, environmental groups, and industry. It would draw on the resources of the EPA and other federal departments and agencies, the National Science Foundation, the Office of Management and Budget, and the Council on Economic Advisers. The Task Force would need to take account of budgetary and other 
part from the regulatory tools used in the U.S. Centralized command-andcontrol approaches, under which federal legislators and regulators establish uniform, national requirements, typically use a "best available technology" approach. The EPA adopts standards on an industry-by-industry basis, requiring each plant within an industry to achieve a specific degree of pollution control, based on what can be achieved by available technology. ${ }^{242}$ This approach is well suited for ensuring widespread adoption by industry of existing "end-of-pipe" control technologies. It is far less successful in dealing with diffuse sources that pose significant risks, such as non-point water pollution, automobile use, small air pollution sources, or household radon.

A technology-based command-and-control approach, as applied in the context of U.S. legal culture, produces a curious, self-contradictory form of central planning through litigation. Central planners must examine the processes and physical situations in different industries and plants in order to specify the level of control which they must achieve. ${ }^{243}$ Controls are specified in excruciating legalistic detail for many different aspects of production processes and for releases into different media. ${ }^{244}$ These control requirements are not coordinated with one another, and operate on different timetables and through different permitting procedures. ${ }^{245}$ The requirements are formulated and implemented through ponderous adversary administrative proceedings. In many instances, the outcome of these administrative proceedings is challenged in court by industry, environmental groups, and other interests. This process produces long delays and high transaction costs. ${ }^{246} \mathrm{It}$

economic constraints that, together with the development of a plan for the coming decade, would facilitate priority-setting. Unlike the Quayle Competitiveness Council, the Task Force's objective would not be merely to weed out particular proposed regulations deemed excessively burdensome in relation to benefits, but to redirect regulatory priorities and promote innovative policy instruments. For analysis of the failings in current environmental regulatory policy that might be redressed by such an approach, see MARK LANDRY et al., The EnVironmental Protection AgenCY: Asking THE Wrong Questions (1990).

242. See, e.g., Standards of Performance for New Stationary Sources, 40 C.F.R. $\$ 60$ (1992) (technology-based emission standards for different industrial categories of new sources).

243. See Richard Stewart, Controlling Environmental Risks Through Economic Incentives, 13 CoLUM. J. ENVTL. L. 153, 155 (1988).

244. The large loose-leaf binders, BNA Environmental Reporter, Federal Regulations, and BNA Environment Reporter State Regulations, comprising 29 volumes, collect a vast array of statutes and regulations whose extent and complexity has no counterpart in any other national legal system.

245. For example, the compliance deadlines established by the hazardous air pollution control provisions of the Clean Air Act, \$ 112, 42 U.S.C. $\$ 7412$ (1988), the "land ban" provisions of the Resource Conservation and Recovery Act dealing with toxic wastes, § 3004(d), 42 U.S.C. § 6924(d) (1988), and the toxic efficient limitation provisions of the Clean Waste Act, $\$ \S 301$ (b), 307, 42 U.S.C. $\$ \$ 1311($ b), 1317 (1988), would often apply to the discharge or generation of the same toxic substance from the same plant, but are implemented through entirely different and independent standard-setting and permit procedures pursuant to entirely different statutory time tables.

246. The distinctive problems of environmental regulation in the U.S. are illustrated in the detailed account of the tortuous evolution of EPA's $\mathrm{SO}_{2}$ New Source Performance Standards for coal-fired electric generating plants in BRUCE A. ACKERMAN \& WILlIAM T. HASSLER, CLEAN COALDIRTY AIR: OR HOW THE CLEAN AIR ACT BECAME A MULTIBILLION-DOLLAR BAIL-OUT FOR HIGH-SULPHUR COAL PRODUCERS AND What SHOULD BE DONE ABOUT IT (1981). 
also diffuses and obscures political responsibility and accountability. ${ }^{247}$ The U.S. Superfund system for financing hazardous waste cleanup through case-bycase litigation seeking to impose strict, retroactive liability on hazardous waste generators and transporters as well as disposal site owners and operators also produces enormous transaction costs. ${ }^{248}$

In order to reduce central information processing overload, central planners tend to adopt uniform requirements that ignore the often wide variations in abatement costs among different sources. Such uniform requirements substantially increase the cost of achieving a given level of pollution reduction as compared to a more flexible approach that would encourage a more costeffective allocation of the abatement burden. For example, numerous studies have shown that under the existing command system, compliance costs run from fifty to several hundred percent greater than if abatement burdens were allocated so as to minimize the total costs to society of limiting pollution to a given level. ${ }^{249}$ With pollution control compliance costs currently in excess of $\$ 120$ billion annually and rising fast, this cost penalty ranges from $\$ 30$ billion to $\$ 60$ billion or more each year. The central command-and-control system also fails to generate strong incentives for conservation, pollution prevention, and innovative investment in new processes and products that are inherently less polluting and capable of achieving greater reductions than existing end-of-pipe controls. ${ }^{250}$ The need for innovation is especially important because regulation has already moved industries far up the cost curve in the process of imposing controls. Achieving more reductions in emissions must be accomplished in large part by encouraging the development of inherently less polluting ways of producing goods and services. ${ }^{251}$

The principal economic competitors of the U.S. among the developed nations generally also use a command-and-control approach to environmental regulation, but the administration of their systems is generally far more

247. See generally Richard B. Stewart, Madison's Nightmare, 57 U. CHI. L. REv. 335 (1990) (arguing that factionalized special interest groups dominate the political-bureaucratic system of national environmental regulation).

248. See ACTON ET AL., supra note 104, at X-xiii.

249. See Alan Carlin, U.S. E.P.A., THE UNITEd STATES EXPERIENCE WITH ECONOMIC INCENTTVES To CONTROL ENVIRONMENTAL POLLuTION, 2-3 to 2-5 (1992) (collecting numerous studies); Ackerman \& Stewart, supra note 79, at 175-77 (1988) (collecting numerous studies); Robert W. Hahn \& Gordon L. Hester, Marketable Permits: Lessons for Theory and Practice, 16 ECOLOGY L.Q. 361, 363 \& nn.3, 13 (1989) (citing one review's conclusion that control costs could be reduced by more than $90 \%$ in some cases).

250. Ackerman \& Stewart, supra note 79, at 175-77. Greater use of these approaches is essential in order to protect the environment while pursuing economic growth. See James Gustav Speth, EPA Must Help Lead an Environmental Revolution in Technology, 21 ENVT'L L. 1425, 1456-57 (1991).

251. See Speth, supra note 250 . Under a best available technology approach, compliance with regulatory requirements usually entails adoption of specified technological controls, locking in today's technologies and retarding creative, new pollution-reducing measures. In addition, the U.S. command system tends to impose unjustifiably disproportionate burdens on new facilities, discouraging new investment and allow old, highly polluting facilities to stay in business. See Paul R. Portney, Air Pollution Policy, in PUBLIC POLICIES, supra note 102, at 27, 89-90. 
flexible, more cooperative, and less legalistic. Industry and government often negotiate over medium to long-term pollution-reduction objectives. ${ }^{252}$

One possible approach to achieving greater flexibility in the U.S. is greater decentralization of decisionmaking authority to state governments. Skepticism about state capabilities and fear of a "race to the bottom" in regulatory standards as a result of state competition for industry underlay the federalization of environmental regulation during the 1970's. ${ }^{253}$ Twenty years later, with the development of solid public and political support for environmental protection throughout the nation and the development of state capacities in the field, there is less reason to worry that devolution will simply result in deregulation. ${ }^{254}$ Environmental constituencies nevertheless distrust state capacities and resolve, and continue to fear a "race toward the bottom."255 In addition, industry often has reason to favor uniform measures that reduce state-by-state disparities and ensure that competitors meet the same standards. While devolution would ameliorate some of the worst problems created by the existing centralized command system, it would not address the inherent limitations of the technology-based regulatory approach. Indeed, state governments with limited administrative resources might be more prone to stick to traditional ways than the federal government. Technology-based standards were an understandable "first generation" response to environmental degradation. However, the problems with ever-more intrusive uses of a command system in the U.S. administrative and legal context compel reconsideration of the prevailing U.S. system of hazardous waste liability and

252. For the experience in Japan, see CONGRESSIONAL BUDGET OFFICE, supra note 98, at 46-47; JULIAN GRESSER ET AL., ENVIRONMENTAL LAW IN JAPAN 229-83 (1981); Bruce E. Aronson, Review Essay: Environmental Law in Japan, 7 HARV. ENVTL. L. REV. 135, 143-47 (1983). For the experience in the United Kingdom, see VoGEL, supra note 58, at 83-87, 226-63.

253. See generally Revesz, supra note 85 (arguing that such fears motivated federal regulation but were misplaced); David Schnapf, State Hazardous Waste Programs under the Federal Resource Conservation and Recovery Act, 12 ENVTL. L. 679 (1992) (discussing evolution of RCRA).

254. Transboundary pollution problems provide a potential alternative justification for federal regulation, but the current federal regulatory system often fails to deal effectively with such problems. For example, the Clean Water Act does not address the problem of interstate water pollution, and the Supreme Court has deferred to EPA discretion in handling the problem. See Arkansas v. Oklahoma, 112 S. Ct. 1046 (1992); City of Milwaukee v. Illinois, 451 U.S. 304 (1981). While the Clean Air Act has a vague substantive provision dealing with interstate air pollution, see $\S 110(a)(2)(D)(i), 42$ U.S.C. $\S 7410(a)(2)(D)(i)(1988)$, no downwind state has been able to invoke it successfully to remedy pollution spillovers from upwind states. See New York v. EPA, 852 F.2d 574, 581 (D.C. Cir. 1988) (R.B. Ginsburg, J., concurring). Federal authority could in any event be retained and strengthened to deal with significant interstate pollution spillovers.

255. See, e.g., Federal Programs Expanded, State Role Increased Under Revised Air Toxics Strategy, 16 Env't Rep. (BNA) 235 (June 7, 1985) (reporting that when EPA proposed giving state agencies more responsibility for regulating many toxic air pollutants, environmentalists opposed the proposal and claimed that the EPA was turning its "long-standing failure to protect the public health from passive neglect into deliberate policy"). For an example of competition between states for jobs, see Steven Prokesch, New Jersey and New York Collide In New Competition to Lure Jobs, N.Y. TIMES, Dec. 1, 1992, at A1; Steven Prokesch, Promises Aside, States in Region Fight With One Another for Jobs, N.Y. Times, Nov. 30, 1992, at Al. 
basic changes in regulatory approach. Two such alternative approaches are environmental contracting and market-based incentives.

\section{Environmental Contracting}

Environmental contracting involves a negotiated agreement between government authorities and industry on comprehensive targets and timetables for reductions of pollution or other risks in lieu of unilaterally imposed, piecemeal regulatory requirements for specific types of pollution from particular sources or process units. As this Section will discuss, environmental contracting is emerging as an important new development in Europe, and its more informal equivalent has been used for a number of years in Japan and elsewhere. Such contracts may be negotiated with an entire industry or on a facility-by-facility basis.

The Netherlands has recently begun to use formal environmental contracts on an industry-wide basis as a means of achieving the ambitious pollution reductions goals contained in its National Environmental Policy Plan. This plan sets comprehensive, multi-media national targets for pollution reduction and environmental improvement over the next twenty years, with interim benchmarks. ${ }^{256}$ Each industry is allocated a designated share of the required reductions and improvements. The responsible government authorities and a number of industry groups, such as the basic metals industry, have signed or are currently negotiating contracts in which the industry agrees to achieve the overall targets assigned to it. ${ }^{257}$ In return, the government agrees to substitute the contractual arrangements for the pollutant-by-pollutant regulations otherwise applicable, and to restrict changes in requirements during the period of the contract. ${ }^{258}$ The plan's purpose is to give industry flexibility to achieve overall reductions in a more cost-effective fashion ${ }^{259}$ and provide it with relative certainty regarding requirements over an extended period of time in exchange for greater reductions than would otherwise be required or

256. See Jyt A. Peters, Voluntary Agreements Between Government and Industry: The Basic Metal Covenant as an Example, in PROCEEDINGS: CONFERENCE ON ENVIRONMENTAL CONTRACTS AND COVENANTS (forthcoming 1993) (manuscript on file with author) [hereinafter PROCEEDINGS]; Pratt, supra note 132 , at 89.

257. See Declaration of Intent on the Implementation of Environmental Policy for the Primary Metals Industry (1991) [hereinafter Declaration of Intent] (on file with author); Peters, supra note 256.

258. Declaration of Intent, supra note 257.

259. Flexibility in adjusting regulatory requirements to the circumstances of particular industries is important in facilitating technological innovation. See OECD, supra note 132 , at 89. 
achieved. ${ }^{260}$ If industry facilities fail to meet their commitments, they face penalties and reinstatement of the traditional regulatory system.

Similar agreements are being negotiated in Germany, ${ }^{261}$ Belgium, ${ }^{262}$ and Denmark. ${ }^{263}$ Japan has followed an approach under which local municipalities negotiate agreements of varying degrees of comprehensiveness with individual industrial facilities. ${ }^{264}$ Other systems, such as the British, display similar flexibility; national requirements are often expressed in broad terms that allow governmental authorities to weigh the costs and benefits of reduction measures in light of the circumstances of particular facilities and local conditions. ${ }^{265}$ Many European nations rely on goals or targets in their environmental regulatory programs. The prevailing U.S. approach is much more legalistic, specifying the precise conduct required of regulated firms and providing scant incentive for them to go beyond the legally required minimum. ${ }^{266}$

The U.S. has had limited experience with the contractual approach. In 1991, EPA Administrator Reilly initiated the $33 / 50$ program under which industry would voluntarily agree to significant overall reductions of toxic pollutants. ${ }^{267}$ Congress adopted an ambitious program of technology-based controls for 191 specified toxic pollutants in section 112 of the 1990 Clean Air Act, ${ }^{268}$ but section 112 also authorizes an alternative "early reduction" program. Industries that achieve a $90 \%$ reduction in toxic pollutants before the EPA promulgates regulations imposing technology-based toxics controls are exempt from compliance with the new regulations for five years after they

260. The contracts are regarded as instruments of private law. There is controversy in the Netherlands over the government's authority to substitute such arrangements for otherwise applicable regulatory requirements. See P.J.J. van Buuren, Environmental Covenants: An Administrative Lawyer's View, in PROCEEDINGS, supra note 256.

In addition to the agreements negotiated between national authorities and various Dutch industries, the City of Rotterdam has signed or is negotiating agreements with various German, French, and Swiss industries discharging heavy metals and toxic chemicals into the Rhine. In exchange for agreements by pollution sources to reduce significantly these discharges, Rotterdam has agreed to suspend the pursuit of jitigation seeking damages for injury caused by the pollution. Rhine Contract 1991: Agreement Between the Municipality of Rotterdam and the 'Verband der Chemischen Industrie e.V.' (1991) (on file with author).

261. See Günter Hager, Environmental Contracts in the German Practice, in PROCEEDINGS, supra note 256.

262. See Hubert Bocken, Environmental Covenants in Belgium, in PROCEediNGS, supra note 256.

263. See Jesper Jorgensen, Environmental Covenants in Denmark, in PROCEEDINGS, supra note 256.

264. See GRESSER, supra note 252 at 229-79; Aronson, supra note 252, at 143-47; Kunimoto Yoshiro, Pollution and Local Government, 18 JAPAN Q. 162 (1971) (discussing importance of local self-government in combatting pollution).

265. See VOGEL, supra note 58 , at 24.

266. See Pratt, supra note 132, at 93.

267. U.S. ENVIRONMENTAL PROTECTION AGENCY, OFFICE OF POLlUTION PREVENTION AND TOXICS, EPA's 33/50 PROGRAM, SECOND PROGRESS REPORT (1992) 1-2. The implicit quid pro quo was that EPA, and perhaps Congress, would moderate the push for detailed controls on toxic pollutants or at least give the participating industries some form of credit for the reductions achieved.

268. Clean Air Act, § 112(h), 42 U.S.C. § 7412(h) (Supp. 1992). 
come into effect. ${ }^{269}$ In this provision, the government is essentially offering a unilateral contract, promising sources flexibility and assurance against future modification of requirements for a limited time. In exchange, the government receives substantial reductions earlier than it could through the cumbersome system of command-and-control regulation, which requires years of rulemaking proceedings and other steps to implement new controls.

The EPA has also experimented with negotiating comprehensive agreements on a facility-by-facility basis. ${ }^{270} \mathrm{~A}$ joint study by Amoco and EPA of Amoco's Yorktown, Virginia refinery found that a comprehensive plant-wide, multi-media approach (including residuals in air, water and on land) would better achieve the goal of reducing overall releases of chemicals from the site than does the existing piecemeal command-and-control system. ${ }^{271}$ It would do so by identifying all sources of releases (some of which are not regulated under current law); taking cross-media effects into account (a piecemeal focus on air pollution may simply take residuals from air discharges and put them into the water); and allowing Amoco to rank all available control options for all sources within the plant and implement the most cost-effective combination. For example, the study found that airborne hydrocarbons could be controlled at roughly the same level as required by current regulations but at only $25 \%$ of the cost, if reductions were targeted at the emissions sources selectively. ${ }^{272}$ The study concluded, however, that the piecemeal deadlines imposed by existing statutes and regulations do not allow sufficient time to plan and implement such an integrated approach. ${ }^{273}$ Accordingly, the project was abandoned. The study observes that the "command-and-control, end-of-pipe treatment" approach used in the U.S. over the past 20 years is not well suited to current environmental policy needs. ${ }^{274}$ This study is a damning indictment of the prevailing U.S. environmental regulatory system.

In order to expand the use of environmental contracting in the U.S., significant changes in existing environmental legislation would be required. As the major federal environmental statutes have been amended over the past 15 years, they have grown progressively more prescriptive and detailed, establishing highly specific mandatory requirements and recipes for EPA regulation, and tight deadlines for implementation. ${ }^{275}$ The broad principles

269. Clean Air Act, $\$ 112(i)(5), 42$ U.S.C. $\$ 7412(i)(5)$ (Supp. 1992).

270. See David Stamps, Making a Case for Facility-Wide Compliance, ENvTL. INFo. Digest, Oct. 1992, at 6-9.

271. See Amoco-U.S. E.P.A. Pollution Prevention Project, Yorktown, Virginia: Executive Summary 15-18 (December 1991, revised May 1992) (on file with author); Stamps, supra note 270.

272. Id. at 11. This option was not feasible because existing regulations would mandate controls on every source, prohibiting flexible reallocation of reductions.

273. Id. at 12-13.

274. Id. at 13-14.

275. See, e.g., Resource Conservation and Recovery Act, $\$$ 3004(d), (g), 42 U.S.C. $\$$ 6924(d), (g) (Supp. 1992) (prohibiting land disposal of various categories of hazardous wastes by specified deadline 
of standing established by federal administrative law ${ }^{276}$ and the "citizen suit" provisions in federal environmental statutes ${ }^{277}$ enable environmental groups or the pollution control authority to bring suit to force the EPA and regulated industry to comply with these requirements and deadlines. ${ }^{278}$ As a result, even if the EPA believed that a negotiated alternative to existing regulatory requirements would be beneficial, both it and the regulated industry could and in many cases would be sued for deviating from the letter of the law.

In order to deal with this quandary, Congress would have to amend the environmental statutes to provide the EPA and industry greater flexibility. Section 112 of the Clean Air Act provides a potential model. ${ }^{279}$ The challenge is threefold: to provide benchmarks to ensure that negotiated agreements result in a net improvement in environmental quality over that which would be achieved by command regulation; to provide credible sanctions against industry nonperformance; and to balance industry's need for stability and predictability against the potential need to change requirements in light of new information. Because Congress and environmental groups have greater reason to trust the Clinton Administration than its Republican predecessors, the new administration should seek to persuade Congress to experiment with the environmental contracting alternative.

\section{Market-Based Incentives for Environmental Protection}

Another approach to promoting more cost-effective, innovative solutions to environmental problems is to adopt market-based approaches in lieu of the existing command approach. ${ }^{280}$ Four basic types of market-based incentives for environmental protection have been proposed. First, taxes or fees require a source to pay the government in proportion to the pollution it emits or the environmental degradation it imposes. ${ }^{281}$ Second, transferable pollution

unless EPA had adopted and disposal facilities had complied with treatment standards designed to minimize hazard); Clean Air Act, $\$ 181,42$ U.S.C. $\$ 7511$ (Supp. 1992) (establishing timetable of deadlines for achievement of ozone standards by different categories of polluted regions); Clean Water Act, $\S 301(\mathrm{~b})$, 33 U.S.C. $\$ 1311$ (b) (establishing various timetables for achievement of effluent limitation requirements). An important reason for these detailed 'action forcing" mandates has been the Democratic Congress' distrust of Republican administrations' commitment to effective environmental protection. See News Conference with the Sierra Club, FED. NEws SERvICE, Oct. 21, 1992, available in LEXIS, Nexis Library, FEDNEW File.

276. See, e.g., Japanese Whaling Assoc. v. American Cetacean Soc., 478 U.S. 221, 230-31 n.4 (1986).

277. See, e.g., Clean Water Act, § 505, 33 U.S.C. § 1365.

278. See generally Richard B. Stewart \& Cass R. Sunstein, Public Programs and Private Rights, 95 HARV. L. REV. 1195 (1982); Cass R. Sunstein, What's Standing After Lujan? Of Citizen Suits, "Injuries," and Article III, 91 MiCH. L. Rev. 163, 220-21, 224-26, passim (1992) (discussing frequency and effectiveness of environmental "citizen suits" and their continued availability even after Article III standing requirements have been made more stringent).

279. See supra text accompanying note 269, 279; Clean Air Act, $\$ 112(i)(5), 42$ U.S.C. $\$ 7412(i)(5)$ (Supp. 1992).

280. See generally CARLIN, supra note 249 (collecting numerous studies).

281. See id., ch. 3 . 
permits require each source to hold permits corresponding to the amount of pollution that it emits. ${ }^{282}$ The government issues or auctions off a limited number of such permits, each entitling the holder to emit a given unit of pollution. Thereafter, permits can be freely exchanged, bought, and sold. Accordingly, the ultimate allocation of pollution rights, and hence of pollution control, among sources is determined by the market, rather than by government regulation. ${ }^{283}$ Third, deposit and return systems ${ }^{284}$ require those who generate waste, or produce or purchase a hazardous product, to pay a fee or deposit, which is returned in whole or in part when the waste or product is properly treated, disposed of, or recycled. Finally, using information strategies ${ }^{285}$ government takes steps to provide consumers with information about the environmental effects of different products and services or their production processes, enabling those consumers who wish to buy "green" commodities to do so and providing market incentives for industry to meet their demand.

All these mechanisms advance environmental protection by creating economic incentives for industry to reduce pollution, wastes, and other forms of environmental degradation while also allowing them the flexibility to adopt or invent the least costly means of doing so. ${ }^{286}$ This Section will focus on fees and transferrable permits, because they are the mechanisms that have been most widely used and that have the greatest potential for displacing the traditional technology-based, command-and-control approach.

Use of fees or transferable permits in lieu of uniform technology-based controls would substantially reduce the overall cost of limiting pollution to a given level. ${ }^{287}$ Both approaches use the price system as a signal and an incentive to reduce environmental degradation. A fee system would directly impose a price on pollution by, for example, imposing a fixed dollar fee for each ton of pollutant emitted. Under a transferable permit system, permits carry a positive market price because their supply is limited; the effect on business decisionmaking is the same as a fee or tax. ${ }^{288}$ Those firms that reduce pollution will reduce their costs of doing business and enjoy a competitive advantage. As opposed to a central planning technique that tells each firm what it should do, fees and tradeable permit systems tell industry: "Here is the social

282. See id., ch. 5 .

283. See Richard B. Stewart, Controlling Environmental Risks Through Economic Incentives, 13 COLUM. J. ENVTL. L. 153, 159-60 (1988).

284. See CARLIN, supra note 249 , ch. 4.

285. See id., ch. 6.3.

286. See Robert W. Hahn \& Robert N. Stavins, Incentive-Based Environmental Regulation: A New Era from an Old Idea?, 18 ECOLOGY L.Q. 1, 7-15 (1991).

287. See Ackerman \& Stewart, supra note 79, at 173-79.

288. Joshua M. Epstein \& Raj Gupta, Controlling the Greenhouse EfFect: Five Global REGIMES COMPARED 18-24 (Brookings Occasional Papers, 1990); Richard B. Stewart \& Jonathan B. Wiener, The Comprehensive Approach to Global Climate Policy: Issues of Design and Practicality, 9 ARIZ. J. INT'L \& COMP. L. 83, $103-10$ (1992). 
cost of pollution; it is up to you to find the cheapest way of minimizing that cost." Typically, some sources can reduce pollution far more cheaply than others. Under the price system, they will do a lot of cleaning up, and either pay less in taxes or hold fewer permits. Sources for whom it is more expensive to clean up will reduce pollution less and pay more taxes or buy more permits. By shifting more of the abatement burden to sources that can reduce pollution more cheaply, economic incentives would greatly reduce the total social cost of achieving any given level of pollution reduction. The cost savings would vary, but they could run anywhere from $25 \%$ to as much as $50 \%$ or more. ${ }^{289}$

The incentives for innovation are both stronger and broader under a system of fees or transferable permits than under a technology-based command system. ${ }^{290}$ Firms will have strong incentives to develop more effective ways of reducing pollution because the new system will enable them to reduce the payment of pollution fees to the government or sell some of their existing permits, and thereby gain a competitive advantage over rivals. ${ }^{291}$ Accordingly, reducing pollution can improve profits for a company. The scope for innovation is broad, because sources have the freedom to select any available means of reducing pollution or waste generation. ${ }^{292}$ Industry can achieve reductions through new production processes, conservation, or changes in raw material inputs, as well as the more traditional end-of-pipe controls. For example, the 1990 Clean Air Act Amendments require electric utilities to reduce emissions of sulfur from fossil fuel combustion by over $50 \%{ }^{293}$ The Amendments establish a system of tradeable sulfur emission allowances. ${ }^{294}$ The flexibility provided by this system encourages utilities to promote energy conservation by their customers whenever it is cheaper to lower sulfur-dioxide emissions by reducing demand rather than by using traditional end-of-pipe controls such as flue gas desulphurization scrubbers. Conservation measures have the added benefit of also reducing $\mathrm{CO}_{2}$ emissions.

From the administrative and political point of view, use of economic incentives dramatically reduces the roles of government central planning and of litigation, with all their attendant costs and dysfunctions. The government simply monitors the output of pollution and determines either the price of pollution or the total quantity allowed, rather than attempting to micro-manage

289. See CARLIN, supra note 249 , at 2-2 to 2-6; Ackerman \& Stewart, supra note 79 , at $175-77$ (1988); Hahn \& Hester, supra note 249 , at $363 \&$ nn.3, 13. As Carlin notes, however, U.S. applications of these incentives often achieve less savings than they could because command-and-control regulatory constraints hamper tradeable permit systems, and regulatory agencies set fees to raise revenue rather than to provide incentives for environmental protection. CARLIN at v-vi.

290. See Stewart, supra note 243 , at 159-160.

291. See Daniel J. Dudek \& John Palmisano, Emissions Trading: Why is this Thoroughbred Hobbled? 13 Colum. J. ENVTL. L. 217, 222-233 (1988).

292. See id. at 234-236.

293. See Susan Dudley, The Future of Clean Air Futures, PuB. UTIL. FoRT., Aug. 1, 1992, at 11.

294. See Clean Air Act, $\S 403(a)$, (b), (d), 42 U.S.C. $\$ 7651$ b(a), (b), (d) (Supp. 1992). 
production decisions by a vast number of firms. The decisions that government must make are thus far fewer.

Which type of economic incentive system is preferable, taxes or transferrable permits? Each has advantages and disadvantages in terms of administrative feasibility and political acceptability. It is easier to set up and administer a tax system because there is no need to make an initial allocation of permits or ensure a well-functioning permits market. ${ }^{295}$ On the other hand, new taxes are politically unpopular. Under a command system, regulations typically provide that a source's emissions may not exceed a specified amount. Emissions up to this limit are "free" to the source, which can use the commons as a dumping ground without charge. Under a fee or transferrable permit system, in contrast, the source must pay a fee or otherwise incur an economic cost for all discharges. ${ }^{296} \mathrm{~A}$ permit system can, however, deal with the problem of industry opposition by handing out free permits to existing sources in proportion to their existing regulatory requirements. ${ }^{297}$ Moreover, taxes would have to be repeatedly increased. Under a permit system, market forces would automatically cause the price of permits to rise as demand for emission rights increased.

The use of taxes and transferrable permits in lieu of command-and-control legislation is attracting growing interest in the U.S. and the European Community. ${ }^{298}$ The U.S. has successfully used tradeable pollution reduction credits to phase out lead in gasoline and to provide flexibility in air pollution control regulation. The ambitious sulfur-trading program established by the 1990 Clean Air Act Amendments has already been noted. ${ }^{299}$ In order to make faster progress in controlling the sources of ozone-type smog, the Los Angeles area has adopted and is beginning to implement a broad trading scheme among sources of volatile organic compounds and oxides of nitrogen. ${ }^{300}$ The experience of the U.S. indicates that market-based schemes can substantially lower compliance costs and stimulate the development of environmentally

295. For discussion of the potential problems in establishing an emissions trading market, see Brennan van Dyke, Note, Emissions Trading to Reduce Acid Deposition, 100 YALE L.J. 2707 (1991).

296. See Stewart, supra note 290 , at 159-160.

297. This was the approach followed in the sulfur-dioxide trading program under the 1990 Clean Air Act Amendments. See Clean Air Act, § 403(a), 42 U.S.C. § 7651b(a) (Supp. 1992).

298. Some Community member states have used effluent charges and levied pollution taxes to deal with pollution, although in most cases the prime objective has been to raise revenue rather than to create incentives for pollution reduction. Effluent fees are imposed on water pollution in Germany and France to cover the costs of waste treatment and other water quality projects and the administrative expenses of government. The basic purpose of the fees is to raise revenue rather than influence discharge levels. The Council and Commission are negotiating over an energy/carbon tax to reduce fossil fuel emissions of $\mathrm{CO}_{2}$. See Report of the Committee on the Environment, Public Health and Consumer Protection on Economic and Fiscal Instruments of Environmental Policy, Eur. Parl. Sess. Doc. A3-0130/91 (May 13, 1991) (photocopy on file with author).

299. See supra notes 293-294 and accompanying text.

300. For a review of these and other applications of market-based incentives in the U.S., see Daniel J. Dudek et al., Environmental Policy for Eastern Europe: Technology-Based Versus Market-Based Approaches, 17 Colum. J. ENVTL. L. 1, 9-10 (1992). 
superior technologies. ${ }^{301}$ The performance of tradeable permit and fee systems in the U.S. has, however, been hampered by the overhang of command-and-control regulatory requirements and reluctance to set fees high enough to have significant incentive effects. ${ }^{302}$ Properly deployed, market incentives would also encourage source reduction, shifts in economic activity among sectors, and structural changes, all of which are integral parts of any long-run pollution prevention strategy. ${ }^{303}$ Given that the disadvantages of command systems are especially acute in the U.S. administrative and legal systems, ${ }^{304}$ competitiveness concerns provide a further justification for expanded use of market-based approaches in the U.S. ${ }^{305}$

\section{International Harmonization of Environmental Standards}

\section{Justifications for Harmonization}

Another potential response to concerns in the U.S. and other developed countries regarding the impact on competitiveness of different national environmental standards and the perceived threat of a worldwide "race toward the bottom" is to eliminate or reduce those differences through international agreements. Yet differences among nations in comparative assimilative capacity make appropriate some differences in national standards. ${ }^{306}$ Moreover, as a practical matter many developing countries would not agree, at least in the short to medium term, to adopt the same environmental standards as the OECD nations. Nor would the latter agree to lower their existing standards.

In addition, as Professor Revesz points out, ${ }^{307}$ if nations compete for mobile capital by lowering their environmental standards, harmonizing standards at a relatively high level will not eliminate such competition altogether. Rather, it will simply shift the competition into other forms, such as lower occupational health and safety standards or lower taxes for funding social programs. If so, one must justify giving priority to eliminating competition in environmental standards.

For these several reasons, it would be neither desirable nor feasible to have internationally uniform standards for all environmental problems. On the other

301. See id:; Hahn \& Hester, supra note 249 , at 404-06 (examining factors affecting efficiency of market-based approaches to environmental regulation).

302. See CARLIN, supra note 249 , at v-vi.

303. See supra notes 290-294.

304. See supra text accompanying notes 102-107, 243-248.

305. Potential new applications of market incentive approaches in the U.S. are discussed in PROJECT 88-ROund II: INCENTIVES FOR ACTION: DESIGNING MARKET-BASED ENVIRONMENTAL STRATEGIES (1991); Dudek et al., supra note 300.

306. See supra notes 58-65 and accompanying text.

307. See Revesz, supra note 85. 
hand, existing national standards may not be adequate. Quite apart from "race to the bottom" concerns, the presence of significant environmental externalities suggests that in many instances national standards may be too low. ${ }^{305}$ Political and administrative failures in many developing countries are also likely to lead to inadequate environmental protection. ${ }^{309}$

In sum, competitiveness concerns alone do not justify and will not lead to agreement on uniform national standards for all significant environmental problems. Efforts at international harmonization should focus on those areas such as product standards, where most nations may benefit economically from common standards, or on environmental problems that create especially serious externalities. In many cases, it may be appropriate to recognize variations in assimilative capacity by narrowing rather than eliminating differences in national standards. In this respect, any efforts at harmonization should accord sufficient attention to the special problems faced by the developing countries in achieving higher levels of environmental protection.

In the area of product regulation, harmonization would benefit consumers in all nations by eliminating differences in environmental standards that undercut producers' ability to achieve economies of scale, increase the transaction costs of complying with different state regulations, and hinder trade and its attendant benefits. ${ }^{310}$ But here, too, differences among nations in assimilative capacity and the social value placed on environmental protection create impediments to common standards. Work to harmonize regulatory and labelling standards for chemicals is proceeding under the auspices of the GATT, OECD, and international environmental and health organizations. ${ }^{311}$ Understandably, it has been much more difficult to harmonize environmental standards for other products, such as automobiles, where differences in assimilative capacity are often much more important. Thus, it makes little sense to have the same automotive emission controls in Mali as in Japan. Harmonization has also been impeded by the insistence of nations, such as the U.S., that others adopt their relatively stringent standards ("harmonization up") or that they retain the right to set standards more stringent than those adopted by international agreement. ${ }^{312}$

308. See supra notes $68-75$ and accompanying text.

309. See supra, note 66-67 and accompanying text.

310. See supra notes 17-19 and accompanying text.

311. See Emma Chynoweth, 1992 and Other Concerns, CHEMICAL WK., Sept. 27, 1989, at 134; Ken Sternberg, GATT Tries Harmony, CHEMICAL WK., Aug. 8, 1990, at 12; U.S., European Officials Plan to Discuss Labeling Imported, Exported Chemicals, 1992 Daily Rep. for Executives (BNA) No. 168, at L-1 (Aug. 29, 1986), available in LEXIS, Nexis Library, DREXEC File.

312. See Paul S. Luiki \& Dale E. Stephenson, Environmental Laws Are Stricter in 'Green'-Influenced Europe, NAT'L L.J., Sept. 30, 1991, at 45; Malissa Hathaway McKeith \& Mary Hall, Environmental Compromise: Striking the Balance Between Trade and Technology, Int'l Env't Daily (BNA), Nov. 20, 1992, available in LEXIS, Nexis Library, BNAIED File; Pesticides, Openness Needed During OECD Bid For Harmonization, EPA Official Says, 1992 Daily Rep. for Executives (BNA) No. 208, at D-20 (Oct. 27, 1992), available in LEXIS, Nexis Library, DREXEC File; Worldwide Health and Safety Standards Likely to Develop Over Next Two Decades, GE Official Says, DAILY LAB. REP., May 28, 1991, at A3. 
Differing national requirements for resource exploitation and manufacturing processes present other considerations. ${ }^{313}$ Harmonization of process measures cannot be justified on the ground that it promotes consumer welfare by removing impediments to trade. Indeed, to the extent that existing variations in national standards appropriately reflect national differences in assimilative capacity and social values, eliminating those differences would reduce consumer welfare. Existing standards are often too low, however, because of two types of externality problems. In the first type of problem, exemplified by transboundary pollution and the destruction within a given country of rare ecosystems and endangered species, part of the costs of environmental degradation are borne by those in other jurisdictions. ${ }^{314}$ In the second type of problem, exemplified by stratospheric ozone depletion, climate changes threatened by greenhouse gas emissions, and over-exploitation of the ocean's resources, all nations face a potential tragedy of the commons. ${ }^{315}$ Some form of collective agreement is necessary to deal with these externalities and to prevent environmental degradation that reduces total welfare. These externalities would exist even without trade, although economic growth resulting from trade liberalization might make these externalities more severe. ${ }^{316}$

It is difficult to reach such agreements for many reasons. Because of their more urgent need for economic development, citizens of developing countries often place a lower value on reducing environmental externalities than citizens of developed countries. ${ }^{317}$ Moreover, these countries often have very limited administrative and technical, as well as general economic, resources. ${ }^{318} \mathrm{~A}$ relatively modest infusion of additional resources from the developed nations could make it possible to strengthen the standards of the developing countries, which would obtain economic and environmental benefits as a result of such

313. The transportation and disposal of industrial wastes presents issues that are different from either products or processes. See Stewart, supra note 10, at 1338-39.

314. See supra text accompanying notes $68-69$.

315. See supra text accompanying notes 70-75.

316. Some economists, however, have argued that economic development could enhance environmental quality by shifting the composition of output away from heavy industry to the high tech, light industry and service sectors, and by increasing wealth, which is associated with political demands for higher levels of environmental quality. See Robert E.B. Lucas et al., Economic Development, Environmental Regulations and the International Migration of Toxic Industrial Pollutions: 1960-88, in WORLD BANK PAPERS, supra note 6, at 67, 72-73; GENE M. GROSSMAN \& ALAN B. KRUEGER, ENVIRONMENTAL EFFECTS OF A NORTH American Tree Trade Agreement (Woodrow Wilson School, Princeton University Discussion Paper No. 158,1992$)$.

317. See Patrick Low \& Raed Safadi, Trade Policy and Pollution, in WORLD BANK PAPERS, supra note 6, at 29,34 .

318. See supra Section II(A)(2) for a discussion of how corruption, lack of political responsiveness, and incompetence may be important factors as well. 
transfers. ${ }^{319}$ Both developed and developing nations would benefit from the protection of ecologically valuable resources, such as tropical rain forests, that are located in developing countries. Developed nations might also benefit from the creation of markets for exports of environmentally superior technologies. They could also benefit by reducing transboundary pollution and other forms of environmental spillovers. The developing countries have some responsibility to deal with these spillovers, but at most only in relation to standards appropriate to their own assimilative capacities as well as to their proportionate contribution to common environmental problems. Once it is acknowledged that differences in national standards are appropriate, such transfers ought not to be dismissed as mere "bribes" to induce other nations to cease improper behavior. ${ }^{320}$ Rather, they may be an essential element in arrangements of mutual advantage and common responsibility.

\section{Precedents for International Harmonization}

The number of international agreements on process standards, negotiated under the auspices of the United Nations Environmental Programs (UNEP), the United Nations Conference on Environment and Development (UNCED) and other intergovernmental organizations, is increasing. Examples include agreements dealing with endangered species, ${ }^{321}$ the development of Antarctica, ${ }^{322}$ hazardous waste treatment, ${ }^{323}$ depletion of stratospheric ozone due to emissions of CFC's and other chemicals, ${ }^{324}$ global climate change, ${ }^{325}$ and biological diversity. ${ }^{326}$ Until recently, most of these agreements did not provide for transfers of resources from developed country signatories to less developed country signatories. The developed countries could, however, follow an informal practice of rewarding those developing

319. Requirements by developed nations that developing nations meet certain environmental standards as a condition of receiving assistance could, however, be resented as a contemporary manifestation of colonialism. See Peggy Au Rodgers, Note, Looking a Gift Horse in the Mouth: The World Bank and Environmental Accountability, 3 GEO. INT'L ENVTL. L. REV. 457, 476 (1990).

320. Cf. Ronald Coase, The Problem of Social Cost, 3 J. L. \& Econ. 1 (1960).

321. See, e.g., Convention on International Trade in Endangered Species of Wild Fauna and Flora, Mar. 3, 1973, 27 U.S.T. 1087, 993 U.N.T.S. 243 [hereinafter CITES].

322. See, e.g., Convention on the Regulation of Antarctic Mineral Resource Activities, June 2, 1988, 27 I.L.M. 868.

323. See, e.g., Basel Convention on the Control of Transboundary Movements of Hazardous Wastes and Their Disposal, Mar. 22, 1989, S. TrEaTY Doc. No. 5, 102d Cong., 1st Sess. (1991), 28 I.L.M. 657.

324. See, e.g., Montreal Protocol on Substances That Deplete the Ozone Layer, Sept. 16, 1987, S. TREATY DOC. No. 10, 100th Cong., 1st Sess. (1987), 26 I.L.M. 1550, amended and adjusted June 29, 1990, 30 I.L.M. 537 [hereinafter Montreal Protocol].

325. See, e.g., Framework Convention on Climate Change, May 9, 1992, 31 I.L.M. 849 [hereinafter Climate Change Convention].

326. See, e.g., Convention on Biological Diversity, June 5, 1992, 31 I.L.M. 818. 
countries who "cooperate" by favoring them with assistance grants or trade liberalization. ${ }^{327}$

Some agreements, such as CITES, ${ }^{328}$ nonetheless impose trade sanctions on those who do not join or honor the agreement. ${ }^{329}$ The Montreal Protocol set an important precedent by explicitly including in the agreement both "sticks," in the form of trade sanctions against nonsignatories, and "carrots," in the form of payments from the more developed to the less developed countries to help finance the costs of phasing out the use of CFC's. ${ }^{330}$ Such inducements were motivated by the urgency and seriousness of the environmental problem in question, stratospheric ozone depletion, and the need for common measures to deal with it. Carrots may be necessary in order to secure the cooperation of developing countries. Sticks may be necessary to overcome free-riding by nonsignatories, who benefit from the signatories' environmental protection efforts and simultaneously enjoy a cost advantage in international competition. ${ }^{331}$

These features of the Montreal Protocol may set a precedent for similar agreements dealing with global environmental externalities, the management of which requires common measures with significant implications for international industrial competitiveness. The developing countries have repeatedly invoked the financial assistance provisions of the Montreal Protocol in global climate negotiations, stating that they will not agree to limitations on greenhouse gas emissions unless the developed countries fund the costs of compliance. ${ }^{332}$ These costs, however, would be very difficult to measure and would, in any event, be many orders of magnitude greater than those involved in phasing out CFC's. On the other hand, adoption by developing countries of energy-efficient development paths and other measures to limit net emissions of greenhouse gases will be essential if restraints on such emissions are to be achieved. The Climate Change Convention provides that the developed countries that are parties to the Convention "shall provide new and additional

327. See Thalif Deen, Environment: Third World Spells Out Its Financial Needs, INTER PRESS SERVICE, Mar. 4, 1992, available in LEXIS, Nexis Library, INPRES File; David Dodwell, Trade and the Environment: GATT Issues Warning Against Environmental Imperialism, FIN. TIMES, Feb. 12, 1992, at 3; Economic Declaration-Building World Partnership, Int'l Trade Daily (BNA), July 26, 1991, available in LEXIS, Nexis Library, BNAITD File; EEC/Asia/Latin America: ALA to Benefit from Financial and Technical Aid and ECIP Extension, EUR. REP., Feb. 28, 1992, at 11, available in LEXIS, World Library, EURRPT File; Andrew Steer, The Environment for Development, FIN. \& DEV., June, 1992, at 18; UNCED: Mixed Bag of Results at Rio Conference, EuR. ENV'T., June 19, 1992, available in LEXIS, World Library, EURENV File [hereinafter UNCED: Mixed Bag].

328. See supra note 321 .

329. See CITES, supra note 321 , art. VIII.

330. See Montreal Protocol, supra note 324, arts. 4 \& 5, S. TREATY Doc. No. 10, at 5-6, 26 I.L.M. at 1554-56.

331. See supra notes $68-75$ and accompanying text.

332. See Carbon Taxes, Tradeable Emissions Permits Suggested to Fund Transfers of Technology, Int'I Env't Daily (BNA), July 10, 1991, available in LEXIS, Nexis Library, BNAIED File; Larry B. Stammer, World Bank May Ignore Climate Fears; Predicted Warming Doesn't Justify Loan Limits, Memo Says, L.A. TIMES, Aug. 31, 1989, at 1. 
financial resources to meet the agreed full costs incurred by developing country Parties" to meet their obligations under the Convention. ${ }^{333}$ The Convention also establishes a fund to help provide such assistance. ${ }^{334}$

\section{Competitiveness Concerns as Impediments to International Agreement}

Negotiation of international agreements to harmonize environmental standards and promote common measures is no easy task. The number of countries is large, their interests are quite diverse and often sharply conflicting, and international institutions are underdeveloped and highly imperfect. Rather than providing a solution to international competitiveness concerns, international negotiations may become a new battleground of economic rivalry as each country or group of countries seeks to "tilt" the structure and content of proposed agreements to its competitive advantage. ${ }^{335}$ For example, in the global climate negotiations the European Community (EC) sought agreement on specific targets and timetables for limiting fossil fuel $\mathrm{CO}_{2}$ emissions. ${ }^{336}$ Leading EC nations, such as Germany, had already concluded that such limitations were desirable for purely economic reasons relating to plant modernization and productivity. ${ }^{337}$ Others, such as France, were committed to expanding their already formidable nuclear generating capacity. ${ }^{338}$ The U.S. has abundant fossil fuel resources, especially coal, which emits higher amounts of $\mathrm{CO}_{2}$ per energy yield than other fossil fuels. ${ }^{339}$ An agreement restricting fossil fuel $\mathrm{CO}_{2}$ emissions would therefore disadvantage U.S. industry relative to industry in the EC. The U.S. opposed limitations on fossil fuel $\mathrm{CO}_{2}$ alone, arguing for a comprehensive approach which would include all greenhouse gases (GHG's), their sources, and their sinks. ${ }^{340}$ OPEC nations, including Saudi Arabia, also opposed fossil fuel $\mathrm{CO}_{2}$ limitations. ${ }^{341}$

333. Climate Change Convention, supra note 325 , art. 4, para. 3.

334. Id., art. 11.

335. Regional economic rivalry is a major factor driving federal environmental legislation in the U.S. ACKERMAN \& HASSLER, supra note 246, at 44-47; B. Peter Pashigian, Environmental Regulation: Whose Self-Interests are Being Protected?, 23 ECON. INQUIRY 551 (1985).

336. See EEB: Message to Government Leaders Ahead of Maastricht Summit, EUR. ENERGY, Nov. 29, 1991, available in LEXIS, Nexis Library, EUREN File; Environment Council: Full Agenda on December 20/21, EUR. REP., Dec. 19, 1990, at 14, available in LEXIS, World Library, EURRPT File; UNCED: Mixed Bag, supra note 327.

337. See Beth Schwinn, Solve Pollution, Earn Money, STATES NEwS SERV., Mar. 13, 1991, available in LEXIS, Nexis Library, SNS File.

338. See State Energy Firm to Spend \$1.9 Billion on Pollution Control Over Next 10 Years, Int'l Env't Daily (BNA), Feb. 1, 1993, available in LEXIS, Nexis Library, BNAIED File.

339. See Advocates Insist Renewable Energy Needs Government Help to Succeed, GLOBAL WARMiNG NETWORK-GWN ONLINE TODAY, Nov. 20, 1991, available in LEXIS, Nexis Library, ZEV1 File; Michael Weisskopf, Rust-Belt Emissions Cloud Earth Summit; U.S. Factories Lag in Energy Efficiency, WASH. POST, June 2, 1992, at Al;.

340. See Clearing the Air; Profile-'92, The MacNeil/Lehrer NewsHour (Educ. Broadcasting, June 15, 1992) (Transcript No. 4356), available in LEXIS, Nexis Library, MACLEH File.

341. See Thomas W. Lippman, Saudi Oil Minister Warns U.S. on New Oil, Gasoline Taxes; Nazer: Moves May Cost Exporters' Cooperation, WASH. POST, Feb. 11, 1993, at B11. 
On the other hand, developing countries like Brazil were concerned about the potential extension of any agreement to include non-fossil $\mathrm{CO}_{2}$ and methane emissions resulting from deforestation. ${ }^{342}$ In the end, no binding limitations were agreed to. The Climate Convention is a framework convention; agreements on specific limitations of GHG emissions must await future protocols. ${ }^{343}$ The EC is debating a proposed energy fuel tax based in part on carbon content of fuel, but at the insistence of European industry the proposal would become effective only if Japan and the U.S. adopted $\mathrm{CO}_{2}$ limiting measures that imposed comparable financial burdens on their industries. ${ }^{344}$

The slow pace of international agreements and the struggle for competitive advantage may lead nations to adopt unilateral trade measures, such as product import bans and taxes, to promote environmental objectives and protect domestic industry. The GATT panel decision invalidating the unilateral U.S. ban on imports of Mexican tuna and the proposed NAFTA agreement with Mexico have created lively controversy about the relation between trade and environmental issues. ${ }^{345}$ The U.S. has been the leader in imposing unilateral restrictions, although it could well become a target if, for example, the EC imposed an energy/carbon tax to curtail $\mathrm{CO}_{2}$ emissions and imposed countervailing duties on imports from the U.S. if it failed to adopt a similar tax. Such measures could be justified as internalizing the external costs of environmental degradation and establishing a level playing field for competition. ${ }^{346}$ The difficulty with these justifications is that the costs of environmental degradation are a function of societal values and other elements of assimilative capacity which vary from nation to nation. ${ }^{347}$ There is no objective or uniform "cost" of pollution. ${ }^{348}$ Given the serious potential for protectionist abuses of unilateral measures based solely on different standards in other countries, the GATT appropriately views such measures as violating international trade law. ${ }^{349}$ Nevertheless, these measures are justified to the extent that they are aimed at transboundary pollution or despoliation of the global commons, and to the extent that they are adopted by a substantial number of nations. ${ }^{350}$ As illustrated by the CFC-related trade restrictions in

342. See Brazil: Prepcom Reps Move to Block Rain Forest Monitoring, GREENwIRE, Mar. 19, 1992, available in LEXIS, Nexis Library, GRNWRE File.

343. For an overview of the Convention and the negotiations that produced it, see Bodansky, supra note 74 .

344. Proposal for a Council Directive Introducing a Tax on Carbon Dioxide Emissions and Energy, COM(92) 226 final at $46-47$.

345. The analysis in the remainder of this paragraph is developed at greater length in Stewart, supra note 10 , at $1353-68$.

346. See Frederic L. Kirgis, Environment and Trade Measures After the Tuna/Dolphin Decision, 49 WASH. \& LEE L. REv. 1219, 1224 (1992); David A. Wirth, The International Trade Regime and the Municipal Law of Federal States: How Close a Fit?, 49 WASH. \& LEE L. REV. 1389, 1399-1401 (1992).

347. See supra notes 58-65 and accompanying text.

348. See Stewart, supra note 10 , at 1333.

349. See GATT Ruling, supra note 20.

350. See Stewart, supra note 10, at 1363-67. 
the Montreal Protocol, international environmental agreements must increasingly address trade issues. At the same time, the GATT and regional trade agreements must increasingly address environmental concerns. ${ }^{351}$

\section{The Use of Economic Incentives in International Harmonization}

The global climate policy debate vividly illustrates the relation between environmental problems, international competitiveness, and environmental policy instruments. The costs of achieving significant limitations on GHG's are enormous. The use of international command-and-control requirements to limit the many different GHG sources and sinks would be extraordinarily cumbersome. It is also doubtful that sufficient transfers of technology and other assistance from the developed to the less developed countries can be achieved through bilateral or multilateral assistance mechanisms. Developed countries' industries are most reluctant to accept costly new GHG limitation requirements that would disadvantage them in international competition. At the same time, some of these industries could enjoy rich market opportunities for sales of resource-efficient, environment-friendly technologies to developing countries. These several factors suggest the desirability of using economic incentives to limit GHG emissions and generate the resources to launch less developed countries on "green" development paths. One option is the imposition of taxes or fees on net GHG emissions, earmarking part of the revenues for transfers to less developed countries. Another is the use of tradeable net GHG emission rights. Under the latter approach, firms in the developed countries could be partially compensated for the transfer of GHGreducing technologies by transfers of GHG emission allowances that less developed countries would no longer need. ${ }^{352}$ Such arrangements could lead to the development of a world market in GHG allowances, a form of "green" currency that would channel technology and resources to wherever in the world net GHG emissions could be reduced at the lowest cost. In addition to providing mechanisms for transfers of capital and technology from developed to developing countries, these economic incentive systems would, for reasons already explained, significantly reduce the costs of achieving reductions and avoid the need to create an elaborate international command-and-control regulatory authority. ${ }^{353}$ Both of these features would promote the likelihood of agreement on targets and timetables for GHG limitations.

351. See John H. Jackson, World Trade Rules and Environmental Policies-Congruence or Confict?, 49 WASH. \& LEE L. REV. 1227, $1255-59$ (1992); Stewart, supra note 10, at 1349-50.

352. See Stewart \& Wiener, supra note 288, at 103-10.

353. There would have to be international agreement on the allocation of allowances. Once such an allocation was established, market transactions and nation-to-nation agreements would determine the extent of controls of different GHG's for particular sources and the extent of preservation and enhancement of particular sinks. Under a command-and-control approach, each of these thousands of particularized decisions would have to be made through some authoritative international process. 
International measures to deal with global climate change represent only one possible application of economic incentive approaches. Other candidates include forest preservation, which could be promoted by a system of tradeable resource rights, and biodiversity. An innovative, market-based approach to preserving biodiversity which could set a broad precedent is an agreement between a major U.S. pharmaceutical company and the Government of Costa Rica in which the company agreed to finance preservation of tropical forest in return for preferential access to the forest's genetic resources. ${ }^{354}$ Economic incentives are not, of course, a panacea for all of the difficulties in developing successful environmental policies in the international context, any more than in the domestic context. Nonetheless as Dean Aman points out, ${ }^{355}$ marketbased environmental protection measures are especially well adapted to the circumstances of a global economy. Such measures avoid the enormous problems of a top-heavy, worldwide command-and-control regulatory authority, and would provide considerable scope to local flexibility and innovation. They would also harness the logic of comparative advantage and the power of market forces to protect the global environment. They would make environmentalists of Adam Smith and David Ricardo.

\section{ConClusion: Competitiveness as a POliticAl Heuristic}

Like so many issues of economic and social policy, questions about the relation between environmental standards, international competition, and welfare are laden with uncertainties that data and economic models cannot fully resolve. The available studies find that environmental compliance outlays in the U.S. are a quite small percentage of production costs for most industries, rising to around $3 \%$ for those most intensively regulated, and have been a substantial but not overwhelming cause of productivity slowdown in the U.S. ${ }^{356}$ Comparative studies of productivity, trade performance, and industry location conclude that national differences in environmental standards are not a major factor in international competition for all but a few pollution-intensive industries. ${ }^{357}$ On the other hand, studies of regulatory costs omit the adverse effects on innovation of liability exposure and regulatory constraints, delays, and uncertainty. ${ }^{358}$ These adverse effects are especially severe in the U.S., due to the exceptional characteristics of its legal and regulatory system. ${ }^{359}$ These characteristics may help explain why, for example, similar

354. See John McPhaul, Costa Rican Accords Conserve Jungle, May Bring Medical Gains, Reuters, Oct. 11, 1991, available in LEXIS, Nexis Library, REUTER File; Andrew Pollack, Not Without the Rain Forests, N.Y. TMiES, Mar. 5, 1992, at D9.

355. See Aman, supra note 3, at 2110, 2118-19, 2122.

356. See supra Section III(C)(1).

357. See supra Sections III(C)(1)-(3).

358. See supra Sections III(A)-(B).

359. See supra Section III(B)(3) \& (C)(1). 
environmental standards have caused much greater productivity losses in the U.S. than in Japan.

Moreover, almost all of the comparative studies are based on 1970's or early 1980's data. The comparative disadvantage of the U.S. legal and regulatory system has become more severe since the mid-1980's, as regulation has intensified and the U.S. alone has adopted sweeping environmental liability rules. Because of these developments, the U.S. at present may be suffering a significantly greater competitiveness disadvantage than identified in the studies. ${ }^{360}$ We are thus confronted with appreciable uncertainty. The extent to which differences among national environmental standards are justified by differences in assimilative capacities, or instead reflect inadequacies due to political failures and environmental externalities, is a question surrounded by further uncertainties. ${ }^{361}$

Unsurprisingly, people tend to resolve these uncertainties according to their own value orientations and policy predilections. Industries with a large stake in international trade, and environmentalists fearful of cutbacks in environmental standards, tend to downplay the potential adverse effect of U.S. environmental standards on the international competitiveness of U.S. industry. Industry representatives who perceive that existing U.S. standards are unduly stringent, and environmentalists who want to export U.S. standards to other nations, tend to believe that competitiveness effects are large. These differences in the interpretation of uncertainty are inevitable and indeed can be useful if managed through political leadership in such a way as to propel policy forward in appropriate new directions.

In the U.S. context, competitiveness concerns could help advance two agendas that are important for reasons independent of the relative global advantage of U.S. industry. The first agenda is to cut down the excessive costs and impediments to innovation and investment endemic to the existing U.S. command regulatory system by improving priority-setting and using alternative approaches for promoting environmental protection, including market-based incentives and environmental contracting. These steps are independently desirable in order to further environmental progress in the U.S. and improve the general performance of the U.S. economy. The other agenda is to promote a degree of international harmonization and strengthening of environmental standards, especially those that deal with significant environmental externalities. These steps could help to minimize the conflicts among environmental, trade, and competitiveness concerns in the rapidly developing global arena.

360. See supra Section III(B)(1).

361. See supra Section II(A). 